Published in final edited form as:

Nat Rev Drug Discov. 2006 March ; 5(3): 247-264. doi:10.1038/nrd1983.

\title{
Adenosine receptors as therapeutic targets
}

\author{
Kenneth A. Jacobson and Zhan-Guo Gao \\ Molecular Recognition Section, Laboratory of Bioorganic Chemistry, Digestive and Kidney \\ Diseases, National Institutes of Health, Bethesda, Maryland 20892-0810, USA.
}

\section{Abstract}

Adenosine receptors are major targets of caffeine, the most commonly consumed drug in the world. There is growing evidence that they could also be promising therapeutic targets in a wide range of conditions, including cerebral and cardiac ischaemic diseases, sleep disorders, immune and inflammatory disorders and cancer. After more than three decades of medicinal chemistry research, a considerable number of selective agonists and antagonists of adenosine receptors have been discovered, and some have been clinically evaluated, although none has yet received regulatory approval. However, recent advances in the understanding of the roles of the various adenosine receptor subtypes, and in the development of selective and potent ligands, as discussed in this review, have brought the goal of therapeutic application of adenosine receptor modulators considerably closer.

Extracellular adenosine acts as a local modulator with a generally cytoprotective function in the body ${ }^{1}$. Its effects on tissue protection and repair fall into four categories: increasing the ratio of oxygen supply to demand; protecting against ischaemic damage by cell conditioning; triggering anti-inflammatory responses; and the promotion of angiogenesis ${ }^{2}$.

There are four known subtypes of adenosine receptors (ARs) - referred to as $A_{1}, A_{2 A}, A_{2 B}$ and $A_{3}$ - each of which has a unique pharmacological profile, tissue distribution and effector coupling (FIG. 1). All four subtypes are members of the superfamily of G-protein-coupled receptors (GPCRs), and are most closely related to the receptors for biogenic amines.

Among the human ARs, the most similar are the $A_{1}$ and $A_{3}$ ARs (49\% sequence similarity) and the $\mathrm{A}_{2 \mathrm{~A}}$ and $\mathrm{A}_{2 \mathrm{~B}} \mathrm{ARs}$ (59\% similarity).

Extracellular adenosine levels are quite variable, depending on the tissue and the degree of stress experienced, and so the basal levels of stimulation of the four subtypes by the endogenous agonist vary enormously. The sources of adenosine are either release through an equilibrative transporter or as a result of cell damage ${ }^{3}$, or nucleotidase-mediated hydrolysis of extracellular adenine nucleotides ${ }^{4}$, which have their own signalling properties that are mediated by purinergic $\mathrm{P} 2$ receptors. Ectonucleotidases, of which the apyrase CD39 and the 5 '-nucleotidase CD73 are prominent examples, are present on the extracellular surface of many tissues and are crucially involved in numerous important functions ${ }^{4}$. For example, in the brain, CD73 is known as a marker of astrocytes (but not neurons). These enzymes

(C) 2006 Nature Publishing Group

Correspondence to K.A.J. kajacobs@ helix.nih.gov.

Competing interests statement The authors declare no competing financial interests.

DATABASES

The following terms in this article are linked online to: Entrez Gene: http://www.ncbi.nlm.nih.gov/entrez/query. fcgi?db=gene $\mathrm{A}_{1} \mathrm{AR}$ | A2AAR | A2BAR | A3AR | CD39 | CD73 | IL-2 | IL-4 | IL-13

OMIM: http://www.ncbi.nlm.nih.gov/entrez/query.fcgi?db=OMIM Huntington's disease | Parkinson's disease Access to this interactive links box is free online. 
rapidly and effectively shift signalling by released adenine nucleotides and their products to signalling through ARs. Astrocytederived adenosine, acting on $\mathrm{A}_{1} \mathrm{ARs}$, has a central role in the integration of synaptic activity by astrocytes that leads to widespread coordination of synaptic networks ${ }^{5}$. Adenosine itself is rapidly metabolized by adenosine kinase ${ }^{6}$ and, to a lesser degree, adenosine deaminase to AMP and inosine, respectively, both of which are less active than adenosine at the ARs.

The development of potent and selective synthetic agonists and antagonists of ARs has been the subject of medicinal chemistry research for more than three decades. In addition, allosteric enhancers of agonist action could allow the effects of endogenous adenosine to be selectively magnified in an event-responsive and temporally specific manner, which might have therapeutic advantages compared with agonists ${ }^{7}$. AR action might also be modulated not only by direct-acting ligands, but by inhibition of the metabolism of extracellular adenosine $^{6}$ or its cellular uptake ${ }^{3}$.

Although the basic science suggests that selective AR modulators have promise for numerous therapeutic applications, including cardiovascular, inflammatory and neurodegenerative diseases, in practice this goal has been elusive. One reason for this is the ubiquity of ARs and the possibility of side effects. In addition, species differences in the affinity of putatively selective ligands complicate preclinical testing in animal models. However, there has been a recent impetus towards novel clinical targets, in part as a result of the discovery of the $\mathrm{A}_{3} \mathrm{AR}$ subtype in the early 1990s and of the elucidation of new roles for adenosine. In this review, we first present an overview of AR signalling, and summarize progress in the development of selective AR modulators. We then discuss the roles of the AR subtypes in disease, and preclinical and clinical results with AR modulators in various conditions.

\section{AR signalling pathways and regulation}

Classically, AR signalling is thought to occur through inhibition or stimulation of adenylyl cyclase (also known as adenylate cyclase), although it is now apparent that other pathways, such as phospholipase $\mathrm{C}$ (PLC), $\mathrm{Ca}^{2+}$ and mitogen-activated protein kinases (MAPKs), are also relevant (FIG. 1).

Activation of the $A_{1} A R$ inhibits adenylyl cyclase activity through activation of pertussis toxin-sensitive $\mathrm{G}$ proteins ${ }^{8,9}$ and results in increased activity of PLC ${ }^{10,11}$. In cardiac muscle and neurons, $\mathrm{A}_{1} \mathrm{ARs}$ can activate pertussis toxin-sensitive $\mathrm{K}^{+}$channels, as well as $\mathrm{K}_{\mathrm{ATP}}$ channels, and inhibit Q-, $\mathrm{P}$ - and $\mathrm{N}$-type $\mathrm{Ca}^{2+}$ channels ${ }^{1}$. Coupling to $\mathrm{K}^{+}$channels in supraventricular tissue is responsible for the bradycardiac effect of adenosine on heart function ${ }^{12}$. In the heart, $\mathrm{A}_{1} \mathrm{AR}$ and $\mathrm{A}_{2 \mathrm{~A}} \mathrm{AR}$ agonistinduced preconditioning has been suggested to occur via modulation of p44/42 extracellular signal-regulated protein kinase (ERK) signalling ${ }^{13}$.

Activation of the $A_{2 A} A R$ increases adenylyl cyclase activity. $G_{s}$ seems to be the major Gprotein associated with $\mathrm{A}_{2 \mathrm{~A}} \mathrm{ARs}$ in the peripheral systems but not in the striatum, where $\mathrm{A}_{2 \mathrm{~A}} \mathrm{AR}$ density is the highest. It has been shown that striatal $\mathrm{A}_{2 \mathrm{~A}} \mathrm{ARs}$ mediate their effects predominantly through activation of $\mathrm{G}_{\mathrm{olf}}{ }^{14}$, which is similar to $\mathrm{G}_{\mathrm{s}}$ and also couples to adenylyl cyclase. In rat tail artery, facilitation of noradrenaline release by activation of the $\mathrm{A}_{2 \mathrm{~A}} \mathrm{AR}$ triggers the PLC and adenylyl cyclase pathways ${ }^{15}$. Activation of the $\mathrm{A}_{2 \mathrm{~A}} \mathrm{AR}$ also induces formation of inositol phosphates to raise intracellular calcium and activate protein kinase $\mathrm{C}$ in COS-7 cells via pertussis toxin-insensitive $\mathrm{Ga} 15$ and $\mathrm{Ga} 16$ proteins ${ }^{16}$, which have limited tissue distribution and interact with most GPCRs. 
The $A_{2 B} A R$ is positively coupled to both adenylyl cyclase and PLC ${ }^{17-20}$. Results indicate that the activation of PLC, through $\mathrm{G}_{\mathrm{q}}$ proteins, mediates many of the important functions of $\mathrm{A}_{2 \mathrm{~B}} \mathrm{ARs}^{21,22}$. Activation of the $\mathrm{A}_{2 \mathrm{~B}} \mathrm{AR}$ by the non-selective agonist NECA increased inositol phosphate formation in human mast cell line HMC-1 (REF. 20), which is not sensitive to cholera or pertussis toxin but is antagonized by the slightly $\mathrm{A}_{2 \mathrm{~B}} \mathrm{AR}$-selective antagonist enprofylline (3-propylxanthine) ${ }^{20}$. The arachidonic acid pathway was also recently demonstrated to be involved in $\mathrm{A}_{2 \mathrm{~B}} \mathrm{AR}$ activation ${ }^{23}$.

The $\mathrm{A}_{3} \mathrm{AR}$ couples to classical second-messenger pathways such as inhibition of adenylyl cyclase $^{24}$, stimulation of $\mathrm{PLC}^{25}$ and calcium mobilization ${ }^{26-29}$. In cardiac cells, $\mathrm{A}_{3} \mathrm{AR}$ agonists induce protection through the activation of $\mathrm{K}_{\mathrm{ATP}}$ channels ${ }^{30}$. RhoA-phospholipase $\mathrm{D} 1$ signalling has been demonstrated to mediate the antiischaemic effect of $\mathrm{A}_{3} \mathrm{ARs}^{31}$. The WNT signalling pathway is involved in $\mathrm{A}_{3} \mathrm{AR}$ agonist-mediated suppression of melanoma cells ${ }^{32}$. In addition, like other ARs, the $A_{3} A R$ couples to MAPK, which could give it a role in cell growth, survival, death and differentiation ${ }^{33,34}$. An $\mathrm{A}_{3} \mathrm{AR}$ agonist inhibits proliferation in A375 human melanoma cells via the phosphatidylinositol 3-kinase-protein kinase B-ERK1/2 pathway ${ }^{35}$.

Phosphorylation and subsequent desensitization of ARs have been studied for all four subtypes. The rapidity of the desensitization depends on the subtype, with the $\mathrm{A}_{3} \mathrm{AR}$ being more rapidly desensitized than the other subtypes ${ }^{36}$. GPCR kinase-mediated mechanisms are thought to have a crucial role in the rapid desensitization of $\mathrm{A}_{2 \mathrm{~A}}$ and $\mathrm{A}_{2 \mathrm{~B}} \mathrm{ARs}^{36}$.

\section{AR agonists and antagonists}

The main approach for discovering AR agonists has been modification of adenosine itself, and the structure-activity relationships of adenosine at ARs have been extensively probed ${ }^{37}$. Most of the useful analogues are modified in the $N^{6}$ - or 2-position of the adenine moiety and in the $3^{\prime}-, 4^{\prime}$ - or $5^{\prime}$-position of the ribose moiety. Highly selective agonists of the various receptor subtypes (FIGS 2,3; TABLE 1) have been designed through both empirical approaches and a semi-rational approach based on molecular modelling 38,39 .

Similarly, the main approach for the discovery of AR antagonists (FIGS 4,5) has been modification of xanthines such as caffeine and theophylline ${ }^{40}$. A modelling approach combining quantitative models of receptor and ligand has been demonstrated to accurately predict the potency of antagonists ${ }^{41}$. Molecular modelling of ARs using information from the crystal structure of the seventransmembrane protein rhodopsin, supported by mutagenesis studies, has also aided in understanding ligand recognition and provided insights into conformational dynamics ${ }^{38,42}$.

The rest of this section summarizes the development of selective agonists and antagonists for each of the receptor subtypes.

\section{A 1 ARs}

Agonist selectivity for $\mathrm{A}_{1} \mathrm{ARs}$ is typically accomplished through substitution at the adenosine $N^{6}$-position, giving rise to compounds such as CPA. The 2-chloro analogue CCPA displays slightly greater $\mathrm{A}_{1} \mathrm{AR}$ affinity than the parent compound CPA. The affinities of these $N^{6}$-substituted derivatives for $\mathrm{A}_{3} \mathrm{ARs}$ are often intermediate between their respective $A_{1} A R$ and $A_{2 A} A R$ affinities. Agonists CPA and CCPA are highly selective for the rat $\mathrm{A}_{1} \mathrm{AR}$ compared with the $\mathrm{A}_{3} \mathrm{AR}$ subtype, but less selective in human tissue. $S(-)$ ENBA is an even more potent and selective agonist for human and rat $A_{1}$ ARs compared with the three other AR subtypes ${ }^{43}$ 
The classical, nonselective xanthine antagonists of ARs, theophylline (1,3dimethylxanthine) and caffeine (1,3,7-trimethylxanthine), display micromolar affinity at $\mathrm{A}_{1}$, $\mathrm{A}_{2 \mathrm{~A}}$ and $\mathrm{A}_{2 \mathrm{~B}} \mathrm{ARs}^{1}$. Potent and selective antagonists for $\mathrm{A}_{1} \mathrm{ARs}$ have been derived by modification of the xanthines, including many 8 -aryl and 8 -cycloalkyl derivatives ${ }^{40}$. One such derivative is DPCPX, which is highly selective for rat $\mathrm{A}_{1} \mathrm{AR}$ compared with the $\mathrm{A}_{2 \mathrm{~A}} \mathrm{AR}$ ( $\sim 500$-fold) and less selective at the human $\mathrm{A}_{1} \mathrm{ARs}$ compared with human $\mathrm{A}_{2 \mathrm{~A}}$ and $\mathrm{A}_{2 \mathrm{~B}}$ ARs. Certain non-xanthine antagonists, such as the inverse agonist WRC-0571, derived from adenine, are $\mathrm{A}_{1} \mathrm{AR}$ selective, even compared with the $\mathrm{A}_{2 \mathrm{~B}} \mathrm{AR}^{44}$.

\section{$A_{2 A}$ ARs}

Substitution with small alkyl amide groups at the $5^{\prime}$-position of adenosine, as in the nonselective agonist NECA, provides increased potency at all the ARs, and this approach was also used to generate CGS21680, which is a moderately $\mathrm{A}_{2 \mathrm{~A}} \mathrm{AR}$-selective agonist in rats (140-fold selectivity for the $\mathrm{A}_{2 \mathrm{~A}} \mathrm{AR}$ compared with the $\mathrm{A}_{1} \mathrm{AR}$ ) but not humans ${ }^{1,43}$. The selective agonist ATL-146e has much greater affinity for the $\mathrm{A}_{2 \mathrm{~A}} \mathrm{AR}$ than CGS21680 ${ }^{45}$. Although most $N^{6}$-substituted adenosine agonists are $\mathrm{A}_{1} \mathrm{AR}$ - or $\mathrm{A}_{3} \mathrm{AR}$-selective, the agonist DPMA (diastereomeric pair) is more than 30 -fold selective for the rat $\mathrm{A}_{2 \mathrm{~A}} \mathrm{AR}$ compared with the rat $A_{1} A R$ and $A_{3} A R$ subtypes, but has similar affinity at human $A_{1}, A_{2 A}$ and $A_{3}$ $\mathrm{ARs}^{43,46}$.

ZM241,385 and SCH 58261 are highly potent and selective $\mathrm{A}_{2 \mathrm{~A}} \mathrm{AR}$ antagonists ${ }^{47,48}$, although ZM241,385 has been shown to bind with intermediate affinity at the human $\mathrm{A}_{2 \mathrm{~B}} \mathrm{AR}^{46,47}$. The phenolic group of ZM241,385 can be radio-iodinated to provide an $\mathrm{A}_{2 \mathrm{~A}} \mathrm{AR}$-selective radioligand ${ }^{49}$. KW 6002, CSC and other 8-styrylxanthines are selective for $\mathrm{A}_{2 \mathrm{~A}} \mathrm{ARs}$ compared with the $\mathrm{A}_{1}, \mathrm{~A}_{2 \mathrm{~B}}$ and $\mathrm{A}_{3} \mathrm{ARs}^{50}$. However, in dilute solution, these compounds suffer from sensitivity to photoisomerization.

\section{$A_{2 B}$ ARs}

The $\mathrm{A}_{2 \mathrm{~B}} \mathrm{AR}$ is the least studied subtype of the AR family ${ }^{51}$. Selective antagonists have been reported; however, adenosine derivatives as selective $A_{2 B} A R$ agonists remain to be developed. Nearly all the known agonists are derivatives of adenosine. A notable exception is the development, on the basis of recent patents, of a series of pyridine-3,5-dicarbonitrile derivatives by IJzerman and colleagues ${ }^{52}$. These compounds act as AR agonists or partial agonists, with varying degrees of AR selectivity ${ }^{52}$, with LUF5835 being the most potent activator of the $\mathrm{A}_{2 \mathrm{~B}} \mathrm{AR}$ ( $\mathrm{EC}_{50}$ of $10 \mathrm{nM}$, FIG. 3a).

Xanthines that have been developed as selective antagonists of the $\mathrm{A}_{2 \mathrm{~B}} \mathrm{AR}$ include MRS1754 and MRE 2029-F20, both of which have been prepared as radioligands ${ }^{53,54}$. Another selective antagonist, $\left[{ }^{3} \mathrm{H}\right]$ OSIP339391, has also recently been radiolabelled for the study of $\mathrm{A}_{2 \mathrm{~B}} \mathrm{ARs}^{55}$

\section{$A_{3}$ ARs}

The prototypical $\mathrm{A}_{3} \mathrm{AR}$ agonist IB-MECA (CF101) and the more selective agonist Cl-IBMECA have been widely used as pharmacological probes in the elucidation of the physiological role of the most recently identified AR subtype, $A_{3}$ (REF. 56). IB-MECA has a $\sim 50$-fold selectivity for rat $\mathrm{A}_{3} \mathrm{ARs}$ over other subtypes in vitro. The related 4-aminobenzyl derivative can be radio-iodinated, giving rise to [ $\left.{ }^{125} \mathrm{I}\right]-\mathrm{I}-\mathrm{AB}-\mathrm{MECA}$, which is widely used as a high-affinity radioligand for $\mathrm{A}_{3} \mathrm{ARs}^{57}$

The $4^{\prime}$-thio modification of adenosine derivatives, explored for its effect on AR selectivity, has produced several highly potent and selective $\mathrm{A}_{3} \mathrm{AR}$ agonists, such as LJ568 (REF. 58). Conformational studies of the ribose moiety and its equivalents indicate that the ring oxygen 
is not required and that the North $(\mathrm{N})$ ring conformation is preferred in binding to the $\mathrm{A}_{3} \mathrm{AR}$. One means of locking the conformation of the ribose-like ring is through use of the bicyclo[3.1.0]hexane ring system, which assumes an (N)-envelope conformation ${ }^{39,42}$. Highly selective $\mathrm{A}_{3} \mathrm{AR}$ agonists were recently reported in the series of $(N)$ methanocarba-5' -uronamide derivatives, including MRS3558, which has a $K_{\mathrm{i}}$ value of 0.29 $\mathrm{nM}$ for the human $\mathrm{A}_{3} \mathrm{AR}^{39}$

The search for $\mathrm{A}_{3} \mathrm{AR}$ antagonists began with the discouraging observation that xanthines such as caffeine and theophylline, the classical antagonists of $A_{1}, A_{2 A}$ and $A_{2 B} A R s-$ typically have low binding affinities for the $\mathrm{A}_{3} \mathrm{AR}^{24}$. Initial findings were reported for rat $\mathrm{A}_{3} \mathrm{AR}$ (before the report of the cloning of the human homologue) and many common xanthines have binding affinities of around $100 \mu \mathrm{M}$ for this receptor. The cloning of the $\mathrm{A}_{3} \mathrm{AR}$ from other species facilitated further investigation of this receptor ${ }^{59}$. For sheep and human $\mathrm{A}_{3} \mathrm{ARs}$, xanthines have intermediate affinity (typically $100 \mathrm{nM}$ for 8-phenylxanthine analogues). There is a marked species dependence of antagonist affinity at the $\mathrm{A}_{3} \mathrm{AR}$, with human affinity typically greatly exceeding that at the rat receptor for xanthine and other non-purine $\mathrm{A}_{3} \mathrm{AR}$ antagonists ${ }^{24,60}$. Therefore, the search for $\mathrm{A}_{3} \mathrm{AR}$ antagonists turned towards more novel heterocyclic systems ${ }^{56}$.

The screening of diverse chemical libraries resulted in the identification of new high-affinity hits for the human $\mathrm{A}_{3} \mathrm{AR}$, including dihydropyridines, flavonoids, pyridines, thiazoles and others, which were then optimized, typically by substitution of aromatic rings ${ }^{40,41,56}$. The dihydropyridine derivative MRS1334 (not active at L-type calcium channels) and the pyridylquinazoline VUF5574 (not selective in rat) are both relatively potent $\mathrm{A}_{3} \mathrm{AR}$ antagonists, with $K_{\mathrm{i}}$ values of 2.7 and $4.0 \mathrm{nM}$, respectively, at the human subtype. The pyridine derivative MRS1523 is a selective $\mathrm{A}_{3} \mathrm{AR}$ antagonist in both rat and human.

PSB-11, which is a selective antagonist for human $\mathrm{A}_{3} \mathrm{ARs}$, was tritiated for characterization of this receptor ${ }^{61}$. Numerous adenine derivatives have been studied as selective antagonists for $A_{1}$ or $A_{2 A} A R s$, and the adenine derivative MRS3777 was recently reported to be highly selective for the human $\mathrm{A} \mathrm{AR}^{62}$

An alternative approach to designing $\mathrm{A}_{3} \mathrm{AR}$ antagonists is to start with high-affinity adenosine derivatives and truncate the molecule in stages to remove the capacity to activate the receptor without compromising high-affinity binding. An initial attempt to find adenine derivatives, such as 9-alkyl- $N^{6}$-iodobenzyladenines, that displayed these characteristics was unsuccessful ${ }^{56}$. A more successful approach either added substituents to adenosine derivatives or rigidified the nucleosides, to reduce their intrinsic efficacy ${ }^{42}$. With more systematic studies of structure-efficacy relationships on substitution of adenosine at the $N^{6}$, ribose and $\mathrm{C} 2$ adenine positions, it became apparent that the efficacy at $\mathrm{A}_{3} \mathrm{ARs}$ is more easily diminished by structural modification than it is at the other AR subtypes ${ }^{42,43}$. In some cases, $N^{6}$-substitution of adenosine $5^{\prime}$-OH derivatives with large groups (for example, substituted benzyl groups or large cycloalkyl rings) reduced the maximal efficacy, leading to decreased efficacy at the $\mathrm{A}_{3} \mathrm{AR}$. For example, CCPA and DPMA, which are full agonists at $\mathrm{A}_{1}$ and $\mathrm{A}_{2 \mathrm{~A}} \mathrm{ARs}$, respectively, are $\mathrm{A}_{3} \mathrm{AR}$ antagonists. This structural insight was used advantageously to obtain the conformationally constrained nucleoside MRS1292, which proved to be a selective $\mathrm{A}_{3} \mathrm{AR}$ antagonist in both rat and human ${ }^{42,60}$.

\section{ARs as targets in cardiovascular disease}

\section{Arrhythmia}

$\mathrm{A}_{1} \mathrm{AR}$ activation has a number of effects in the cardiovascular system, including a reduction in heart rate and atrial contractility, and the attenuation of the stimulatory actions of catecholamines on the heart ${ }^{63,64}$. Activation of the $A_{1} A R$ by intravenous infusion of 
adenosine (Adenocard; Astellas Pharma) is used to restore normal heart rhythm in patients with paroxysmal supraventricular tachycardia (PSVT). However, for more long-term indications, selective $\mathrm{A}_{1} \mathrm{AR}$ modulators are needed to avoid side effects related to other $\mathrm{AR}$ subtypes such as hypotension.

Selodenoson (DTI0009, GR 56072, RG 14202; Aderis Pharmaceuticals) is a potent and selective $\mathrm{A}_{1} \mathrm{AR}$ agonist with the potential to control heart rate without lowering blood pressure $^{65}$. It has been tested in Phase II clinical trials for its capacity to slow heart rate in atrial fibrillation, although it has been reported to have renal toxicity. Tecadenoson (CVT-510) is a potent $\mathrm{A}_{1} \mathrm{AR}$ agonist with a dose-dependent negative dromotropic effect on the AV node ${ }^{66}$. In patient trials (now Phase III), it terminated PSVT without the side effects associated with other AR subtypes, such as hypotensive effects. CVT-2759 is a partial agonist of the $\mathrm{A}_{1} \mathrm{AR}$, which in guinea pig heart seems to be useful in slowing down $\mathrm{AV}$ nodal conduction and thereby ventricular rate without causing AV block, bradycardia, atrial arrhythmias or vasodilation ${ }^{63}$. SDZ WAG 994 was extensively characterized in clinically relevant models ${ }^{67}$ and has been in Phase I clinical trials for the potential treatment of PSVT. However, development of this agent was discontinued in 1999.

\section{Ischaemia}

Adenosine is released in large amounts during myocardial ischaemia, resulting in effective pre-conditioning in cardiomyocytes through the activation of $A_{1}$ and $A_{3} A s^{29-31,68}$. Administration of a synthetic AR agonist to activate either or both of these receptors might therefore be beneficial to the survival of the ischaemic heart.

Ischaemic cardiac preconditioning by the $\mathrm{A}_{1} \mathrm{AR}$ involves a series of intracellular events that begin with the activation of the receptor and end at the sensitive $\mathrm{K}+$-ATP channels of the mitochondria. Most of the pharmacological data indicate that $A_{1}$ ARs have an important role in protection of the heart and brain from ischaemia-reperfusion injury ${ }^{1}$. The $A_{1} A R$-agonistinduced decreases in blood pressure and heart rate are mediated by the peripheral $\mathrm{A}_{1} \mathrm{ARs}$, with little or no contribution of central $\mathrm{A}_{1} \mathrm{ARs}$, which is consistent with the observation that typical agonists cross the blood-brain barrier to only a small degree ${ }^{69}$. An important role of the $\mathrm{A}_{1} \mathrm{AR}$ in protection of the murine heart by remote, delayed adaptation has been demonstrated ${ }^{70}$.

Cardiac overexpression of $\mathrm{A}_{1} \mathrm{ARs}$ in mouse heart results in substantial protection from ischaemia-reperfusion injury ${ }^{71-73}$. Hearts isolated from transgenic animals with overexpression of $\mathrm{A}_{1} \mathrm{ARs}$ have a lower basal rate than those of control mice ${ }^{71}$. Cardioprotection in wild-type hearts and hearts overexpressing $\mathrm{A}_{1}$ ARs was mediated by mitochondrial $\mathrm{K}^{+}$-ATP channel activation ${ }^{74}$. $\mathrm{A}_{1} \mathrm{AR}$ overexpression also improves myocardial tolerance to anoxia reoxygenation, in addition to protecting hearts from ischaemia-reperfusion injury ${ }^{75}$. The cardiovascular effects of the $\mathrm{A}_{1} \mathrm{AR}$ agonist CPA also convey protection against Sarin poisoning ${ }^{76}$.

It is well documented that adenosine can protect tissues against hypoxia or ischaemia through $\mathrm{A}_{1} \mathrm{ARs}$. In the $\mathrm{A}_{1} \mathrm{AR}$-knockout mouse heart, baseline contractile function and heart rate were unaltered, but intrinsic myocardial resistance to ischaemia was limited ${ }^{77}$. In addition, non-selective receptor agonism induced by 2-chloroadenosine was cardioprotective in $\mathrm{A}_{1} \mathrm{AR}$-knockout (albeit to a lesser extent) and wild-type hearts, indicating additional protective mechanisms through other AR subtypes.

Various lines of evidence indicate that the $\mathrm{A}_{3} \mathrm{AR}$ has a role in protecting the heart ${ }^{68,78}$. Overexpression of $\mathrm{A}_{3} \mathrm{ARs}$ decreases heart rate, preserves energetics and protects ischaemic hearts ${ }^{79}$, and low-level expression of $\mathrm{A}_{3} \mathrm{ARs}$ in the heart provides effective protection 
against ischaemic injury without detectable adverse effects, although higher levels of $\mathrm{A}_{3} \mathrm{AR}$ expression lead to the development of a dilated cardiomyopathy ${ }^{80}$. Paradoxically, global deletion of the $\mathrm{A}_{3} \mathrm{AR}$ in mice also confers resistance to myocardial ischaemic injury and does not prevent early preconditioning ${ }^{81}$. In an isovolumic Langendorff perfusion model, $\mathrm{A}_{3}$ AR-knockout mice also had improved functional recovery and tissue viability during reperfusion after ischaemia when compared with control mice ${ }^{78}$. In one study, administration of an $\mathrm{A}_{3} \mathrm{AR}$ agonist in wild-type and $\mathrm{A}_{3} \mathrm{AR}$-knockout mice showed similar cardioprotective effects: post-ischaemic recovery was enhanced in $\mathrm{A}_{3} \mathrm{AR}$-knockout mice ${ }^{82}$, implying action of the agonist at a non- $\mathrm{A}_{3} \mathrm{AR}$, probably the $\mathrm{A}_{2 \mathrm{~A}} \mathrm{AR}$. It has been demonstrated that, in addition to the role of $\mathrm{A}_{1}$ and $\mathrm{A}_{3} \mathrm{AR}$ agonists, the $\mathrm{A}_{2 \mathrm{~A}} \mathrm{AR}$ activation is protective against ischaemia-reperfusion injury in mice, which has been proposed to be mainly due to its actions on lymphocytes ${ }^{83}$.

An $A_{3}$ AR-mediated direct cardioprotective effect has been evident ${ }^{31}$. However, the $\mathrm{A}_{3} \mathrm{AR}$ expression level is low in cardiomyocytes. So, an indirect protective effect has also been proposed, for example, through modulation of the function of mast cells and neutrophils, in which $\mathrm{A}_{3} \mathrm{ARs}$ are abundant. $\mathrm{A}_{3} \mathrm{AR}$ signalling in rodent mast cells may be detrimental to the myocardium because of a pro-inflammatory mechanism, but this response might only be observed in rodents (that is, mouse $\mathrm{A}_{3} \mathrm{AR}$-knockout experiments) because mast cell degranulation seems to be $\mathrm{A}_{2 \mathrm{~B}} \mathrm{AR}$-dependent in humans and dogs ${ }^{1}$. This could at least in part explain the paradoxical effects observed in various experiments ${ }^{75,81,82}$. Another explanation of the paradoxical effect could be the numerous compensatory mechanisms observed in receptor-knockout mice ${ }^{84}$.

Some studies have shown that activation of either $A_{1}$ or $A_{3}$ ARs could trigger protection of function in preconditioned rat hearts, although maximal preconditioning requires activation of both $\mathrm{A}_{1}$ and $\mathrm{A}_{3} \mathrm{ARs}^{85,86}$. The selective agonists CCPA and Cl-IB-MECA have been used to discern two separate $A_{1}$ and $A_{3} A R$-mediated pathways leading to cardioprotection, either as early or late preconditioning or during prolonged ischaemia. Unlike the case of $\mathrm{A}_{1} \mathrm{AR}$ mediated cardioprotection, $\mathrm{A}_{3} \mathrm{AR}$-mediated cardioprotection is achieved in vivo in the absence of haemodynamic side effects, such as hypotensive effects, and could therefore be therapeutically more promising ${ }^{68}$. Stimulation of $\mathrm{A}_{3}$ ARs could also be advantageous over $\mathrm{A}_{1} \mathrm{AR}$ activation because it may be less likely to induce bradycardia ${ }^{85}$. The $\mathrm{A}_{3} \mathrm{AR}$ agonist $\mathrm{CP} 608039$ is in development for use in perioperative cardioprotection ${ }^{78}$, and the $\mathrm{A}_{3} \mathrm{AR}$ agonist Cl-IB-MECA protects rat cardiac myocytes from the toxicity induced by the cancer chemotherapeutic agent doxorubicin ${ }^{87}$.

\section{Vasodilation}

The $\mathrm{A}_{2 \mathrm{~A}} \mathrm{AR}$ is involved in vasodilation in the aorta and coronary artery ${ }^{1}$. It was suggested that the tachycardic effect of $\mathrm{A}_{2 \mathrm{~A}} \mathrm{AR}$ activation is mediated by centrally located receptors, whereas its hypotensive effect is mediated by the peripheral $\mathrm{A}_{2 \mathrm{~A}} \mathrm{AR}^{69}$. In the late 1960 s and 1970s, metabolically stable AR agonists were tested clinically as antihypertensives, and this was an intended use of the $\mathrm{A}_{2 \mathrm{~A}} \mathrm{AR}$ agonist CGS21680; however, its clinical path was curtailed following canine haemodynamic studies due to in vivo non-selectivity related to spare receptors. In platelets, an $\mathrm{A}_{2 \mathrm{~A}} \mathrm{AR}$ agonist was shown to inhibit aggregation by increasing intracellular cAMP levels, suggesting that adenosine agonists might have utility as antithrombotic agents ${ }^{88}$.

Recently, there has been an effort to further improve subtype-selectivity of $\mathrm{A}_{2 \mathrm{~A}} \mathrm{AR}$ agonists for novel therapeutic applications, including imaging. Adenosine, under the name Adenoscan (Astellas Pharma), is used in myocardial stress imaging to evaluate coronary artery disease by achieving vasodilation in patients unable to exercise adequately. Regadenoson (CVT-3146), a potent and selective $\mathrm{A}_{2 \mathrm{~A}} \mathrm{AR}$ agonist, is being evaluated in 
Phase III studies for the same purpose during myocardial perfusion imaging ${ }^{89}$. The selective $\mathrm{A}_{2 \mathrm{~A}} \mathrm{AR}$ agonist binodenoson (WRC-0470) has entered Phase III clinical trials and seems to be well tolerated as a short-lived coronary vasodilator and acts as an adjunct to radiotracers in imaging ${ }^{90}$. ATL-146e, the most selective of these $\mathrm{A}_{2 \mathrm{~A}} \mathrm{AR}$ agonists, has also entered Phase III clinical trials for coronary imaging.

Activation of the $\mathrm{A}_{2 \mathrm{~B}} \mathrm{AR}$ induces vasodilation in some vascular beds ${ }^{91,92}$, such as the main pulmonary artery of guinea pigs, and induces human chorionic vasoconstriction and signals through the arachidonic acid cascade ${ }^{23}$. The $\mathrm{A}_{2 \mathrm{~B}} \mathrm{AR}$ is selectively upregulated by hypoxia, and $A_{2 B} A R$ antagonists effectively neutralize ATP-elicited reduction in post-hypoxic endothelial permeability ${ }^{93}$. Inhibition of mitosis of rat aortic smooth-muscle cells has been achieved through selective $\mathrm{A}_{2 \mathrm{~B}} \mathrm{AR}$ activation ${ }^{94}$. The $\mathrm{A}_{2 \mathrm{~B}} \mathrm{ARs}$ are also important for adenosine-mediated inhibition of cardiac fibroblast functions ${ }^{95}$ and the stimulation of nitric oxide production during $\mathrm{Na}^{+}$-linked glucose or glutamine absorption ${ }^{96}$. Activation of the $\mathrm{A}_{2 \mathrm{~B}} \mathrm{AR}$ promotes angiogenesis by increasing the release of angiogenic factors ${ }^{2,97}$.

Cutaneous vasopermeability, which is associated with activation and subsequent degranulation of mast cells, is completely lost in mice lacking functional $\mathrm{A}_{3} \mathrm{ARs}^{98}$. One of the well-known actions of adenosine is to dilate vascular beds. Interestingly, the concentration of cAMP is higher in the aortae of $\mathrm{A}_{3} \mathrm{AR}$-deficient mice, with no significant change in the amount of $\mathrm{A}_{1}$ or $\mathrm{A}_{2 \mathrm{~A}}$ ARs, than it is in control mice. The hypotensive effect observed after intravenous adenosine injection in mice lacking the $\mathrm{A}_{3} \mathrm{AR}$ was significantly larger than in control mice ${ }^{99}$. Genetic deletion of the $\mathrm{A}_{3} \mathrm{AR}$ or antagonism of the $\mathrm{A}_{3} \mathrm{AR}$ augmented coronary flow induced either by adenosine or by the $\mathrm{A}_{2 \mathrm{~A}} \mathrm{AR}$ agonist CGS21680 (REF. 100). However, $A_{3} A R s$ do not regulate atherogenesis; the development of atherosclerosis and response to injury of the femoral artery were similar to those in wildtype mice ${ }^{101}$.

It has been clearly demonstrated that both agonist- and antagonist-binding profiles for the murine and human $\mathrm{A}_{3} \mathrm{ARs}$ are different. The marked species difference, together with the paradoxical protection in $\mathrm{A}_{3} \mathrm{AR}-$ knockout hearts despite $\mathrm{A}_{3} \mathrm{AR}$-mediated protection in wild-

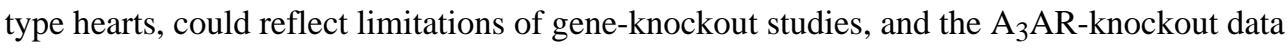
from mice should be interpreted with caution. Also, it should be noted that the selective ligands currently available are only relatively selective for a certain AR subtype. At relatively high concentrations, these ligands may also activate or block other AR subtypes. As such, cautious and thoughtful interpretation of pharmacological data is necessary.

\section{ARs as targets in nervous system disorders}

Observations of the effects of caffeine - a classical AR antagonist - on the nervous system, such as enhancement of awareness and learning, have encouraged the investigation of selective AR antagonists in the nervous system. Indeed, the $\mathrm{A}_{1} \mathrm{AR}$ was recently shown to be involved in the discriminative-stimulus effects of caffeine ${ }^{102}$. However, it is the $\mathrm{A}_{2 \mathrm{~A}} \mathrm{AR}$, which was the first AR to be genetically deleted ${ }^{103}$, that is the primary mediator of the behavioural stimulatory effects of caffeine ${ }^{103-105}$, and this receptor also has an important role in sleep regulation (see below) ${ }^{106}$. Although high concentrations of caffeine can also block phosphodiesterases, which can have numerous behavioural consequences ${ }^{104}$, most of the varied stimulant and other behavioural effects of caffeine are thought to result from antagonism of ARs in the nervous system. This suggests that modulation of ARs may provide therapeutic targets in nervous system disorders, in such diverse conditions as dementia and other neurodegenerative diseases, hyperactivity, anxiety, schizophrenia and sleep disorders. 


\section{Dementia and anxiety disorders}

Recently, the novel A AR-selective antagonist FR194921 (which did not show any species differences in its high $\mathrm{A}_{1} \mathrm{AR}$ affinity) was reported to have potential in the treatment of dementia and anxiety disorders ${ }^{107}$. FR 194921 was orally active and centrally available, ameliorated scopolamineinduced memory deficits, and also showed anxiolytic effects in the elevated plus maze test, without influencing general behaviour or having antidepressant activity ${ }^{107}$.

\section{Pain}

Adenosine exerts multiple influences on pain transmission at peripheral and spinal sites. At peripheral nerve terminals in rodents, $\mathrm{A}_{1} \mathrm{AR}$ activation produces antinociception by decreasing cAMP levels in the sensory nerve terminal ${ }^{108}$. Mice lacking functional $A_{1} A R$ show signs of increased anxiety and hyperalgesia, and the analgesic effects of adenosine observed in wild-type mice are lost ${ }^{109}$. A recent study using $\mathrm{A}_{1} \mathrm{AR}$-knockout mice suggested that $\mathrm{A}_{1} \mathrm{ARs}$ might be more important in chronic pain than in acute pain ${ }^{110}$. In humans, infusion of adenosine in the spinal cord was effective in decreasing post-operative pain $^{111}$.

The $A_{1}$ AR agonist GR79236 administered in cats had a dose-dependent inhibitory effect on trigeminovascular nociceptive transmission, which is otherwise associated with the initiation of local increases in blood flow and enhanced protein permeability - that is, factors that contribute to vascular headaches ${ }^{112}$. $A_{1}$ AR activation leads to neuronal inhibition without concomitant vasoconstriction, indicating that this might be an effective treatment of migraine and cluster headache. Another $\mathrm{A}_{1}$ AR agonist, GW-493838, was evaluated in Phase II clinical trials for the treatment of pain and migraine, and was found to inhibit electrically induced nociceptionspecific blink reflex responses ${ }^{113}$. The $\mathrm{A}_{1} \mathrm{AR}$-selective allosteric enhancer T-62 (FIG. 6) was also shown to reduce hypersensitivity in carageenin-inflamed rats by a central mechanism ${ }^{114}$. T-62 has entered Phase I clinical trials as a treatment for neuropathic pain.

\section{Parkinson's disease}

Some of the symptoms of Parkinson's disease are thought to be caused by a deficit in dopamine release in the striatum. Interestingly, in this respect, various lines of evidence indicate that interaction between the $A_{2 A} A R$ and dopamine $D_{2}$ receptors $\left(D_{2} R s\right)$ in the striatum is antagonistic. The $\mathrm{A}_{2 \mathrm{~A}} \mathrm{AR}$ is co-expressed with $\mathrm{D}_{2} \mathrm{Rs}$ in the striatum and heterodimerization of $A_{2 A} A R$ and $D$ R subtypes inhibits $D_{2} R$ function ${ }^{1,115}$. In SH-SY5Y human neuroblastoma cells, $\mathrm{A}_{2 \mathrm{~A}} \mathrm{AR}-\mathrm{D}_{2} \mathrm{R}$ heteromeric complexes undergo co-aggregation and co-internalization as a result of long-term exposure to $\mathrm{A}_{2 \mathrm{~A}} \mathrm{AR}$ or $\mathrm{D}_{2} \mathrm{R}$ agonists ${ }^{116}$. Independent action of the $\mathrm{A}_{2 \mathrm{~A}} \mathrm{AR}$ and $\mathrm{D}_{2} \mathrm{R}$ has also been proposed in $\mathrm{A}_{2 \mathrm{~A}} \mathrm{AR}$-knockout studies ${ }^{117}$. In $\mathrm{D}_{2} \mathrm{R}$-knockout mice, $\mathrm{A}_{2 \mathrm{~A}} \mathrm{AR}$ agonists and antagonists produce behavioural and cellular functions that are similar to those of their wild-type counterparts, suggesting a $\mathrm{D}_{2} \mathrm{R}$-independent mechanism ${ }^{118,119}$.

The possible antagonistic relationship between $\mathrm{A}_{2 \mathrm{~A}} \mathrm{ARs}$ and $\mathrm{D}_{2} \mathrm{Rs}$ in the striatum has provided a rationale for evaluating $\mathrm{A}_{2 \mathrm{~A}} \mathrm{AR}$ antagonists in Parkinson's disease. In addition, epidemiological evidence shows an inverse relationship between caffeine consumption and risk of developing Parkinson's disease ${ }^{120,121}$. $\mathrm{A}_{2 \mathrm{~A}} \mathrm{AR}$ antagonists not only provide symptomatic relief but also decelerate the neurodegeneration of dopaminergic cells in patients with Parkinson's disease ${ }^{119}$. An $\mathrm{A}_{2 \mathrm{~A}} \mathrm{AR}$ antagonist, KW-6002 (istradefylline), has shown potential in a recently completed Phase II clinical trial (now in Phase III trials) as a novel treatment for Parkinson's disease ${ }^{123,124}$, and other $\mathrm{A}_{2 \mathrm{~A}} \mathrm{AR}$ antagonists, such as V2006 (a derivative of the antimalarial drug mefloquine), are in development ${ }^{124-126}$. V2006, which 
is beginning Phase II clinical trials, is well tolerated in high doses, and its pharmacokinetic properties suggest that it should be suitable for daily dosing.

\section{Ischaemia and neuroprotection}

Pharmacological characterization of $\mathrm{A}_{2 \mathrm{~A}} \mathrm{AR}$-knockout mice has shown that $\mathrm{A}_{2 \mathrm{~A}} \mathrm{AR}$ inactivation protects against neuronal cell death induced by ischaemia ${ }^{127,128}$ and the mitochondrial toxin 3-NP (an animal model of Huntington's disease) ${ }^{129}$. Yu et al. ${ }^{130}$ recently created a chimeric mouse model in which $\mathrm{A}_{2 \mathrm{~A}} \mathrm{AR}$ knockout is combined with bone marrow transplantation. Selective reconstitution of $\mathrm{A}_{2 \mathrm{~A}} \mathrm{ARs}$ in bone marrow cells of $\mathrm{A}_{2 \mathrm{~A}} \mathrm{AR}$-knockout mice abolished the neuroprotection against ischaemic brain injury in global $\mathrm{A}_{2 \mathrm{~A}} \mathrm{AR}$-knockout mice. Conversely, selective inactivation of $\mathrm{A}_{2 \mathrm{~A}} \mathrm{ARs}$ by transplantation of bone marrow cells-derived cells from $\mathrm{A}_{2 \mathrm{~A}} \mathrm{AR}$-knockout mice into wildtype mice attenuated infarct volumes and ischaemia-induced expression of several proinflammatory cytokines in the brain. The finding indicated the possible use of $\mathrm{A}_{2 \mathrm{~A}} \mathrm{ARs}$ on bone marrow-derived cells for the treatment of ischaemic brain injury. In contrast to adult mice, in newborn $\mathrm{A}_{2 \mathrm{~A}} \mathrm{AR}$-knockout mice, brain damage is aggravated after hypoxic ischaemia $^{131}$.

The seemingly paradoxical protective effects of both $\mathrm{A}_{2 \mathrm{~A}} \mathrm{AR}$ agonism and antagonism indicate the degree of complexity of the system, and the dependence of the results on developmental stage and the specific mechanism of injury. Studies have also shown that $\mathrm{A}_{2 \mathrm{~A}} \mathrm{AR}$ agonists result in neuroprotection in some experimental conditions, including cerebral haemorrhagic injury ${ }^{132}$ and ischaemia-reperfusion injury in the spinal cord ${ }^{133}$.

In the brain, adenosine released under stress conditions counteracts the release and damaging effects of excitatory neurotransmitters, such as glutamate, by activation of the $\mathrm{A}_{1} \mathrm{AR}$. ADAC, an $\mathrm{A}_{1} \mathrm{AR}$ agonist, was potent in cerebroprotection in a model of global ischaemia in gerbils ${ }^{134}$. The $\mathrm{A}_{1} \mathrm{AR}$ agonist NNC-21-0136 was neuroprotective in both global and focal rodent ischaemia models and had diminished cardiovascular effects in rats compared with reference $\mathrm{A}_{1} \mathrm{AR}$ agonists, such as $\mathrm{CPA}^{135}$. However, it was recently shown that deletion of the gene that encodes the $\mathrm{A}_{1} \mathrm{AR}$ does not alter neuronal damage that occurs after ischaemia in vivo or in vitro ${ }^{136}$, although $\mathrm{A}_{1} \mathrm{ARs}$ have been shown to be relevant to hypoxia protection in newborn mice ${ }^{137}$. Glial cells express all the ARs, and $\mathrm{A}_{2 \mathrm{~A}} \mathrm{AR}$ activation was found to promote myelination in Schwann cells, suggesting that a selective agonist could be useful in treating demyelinating diseases such as multiple sclerosis ${ }^{138}$. Although $\mathrm{A}_{3} \mathrm{AR}$ expression levels are low in all regions of the brain ${ }^{139-141}$, an $\mathrm{A}_{3} \mathrm{AR}$ agonist (IB-MECA) depresses locomotor activity in mice ${ }^{142}$, suggesting a role for the $\mathrm{A}_{3} \mathrm{AR}$ in depression of motor activity. Chronic administration of the $\mathrm{A}_{3} \mathrm{AR}$ agonist IB-MECA was highly effective in a gerbil model of cerebroprotection against global ischaemia ${ }^{143}$, and deletion of the $\mathrm{A}_{3} \mathrm{AR}$ has a detrimental effect in a model of mild hypoxia, suggesting the possibility of using $\mathrm{A}_{3} \mathrm{AR}$ agonists to treat cerebral ischaemia.

\section{Sleep}

Adenosine has been found to be an important endogenous sleep-promoting substance ${ }^{144,145}$. It mediates the somnogenic effects of prior wakefulness, and also seems to have an important role in the regulation of the duration and depth of sleep after wakefulness ${ }^{144}$.

Pharmacological data suggest that $\mathrm{A}_{1} \mathrm{ARs}$ are involved in the regulation of sleep ${ }^{145}$, but lack of $A_{1} A R s$ does not prevent the homeostatic regulation of sleep ${ }^{146}$. Therefore, it is possible that although the $\mathrm{A}_{1} \mathrm{AR}$ is an important factor for sleep regulation in normal animals, other factors, such as the $A_{2 A} A R$, could compensate for the role of $A_{1} A R$ when it is deleted. Indeed, it was recently shown that the $\mathrm{A}_{2 \mathrm{~A}} \mathrm{AR}$ has a key role in adenosine-mediated sleep- 
promoting effects ${ }^{147}$. It has been suggested that the cholinergic basal forebrain is an essential area for mediating the sleep-inducing effects of adenosine by inhibition of wakefulness-promoting neurons via the $\mathrm{A}_{1} \mathrm{AR}$, and the $\mathrm{A}_{2 \mathrm{~A}} \mathrm{AR}$ in the subarachnoid space below the rostral forebrain could have a role in the prostaglandin $\mathrm{D}_{2} \mathrm{R}$-mediated somnogenic effects of adenosine ${ }^{148}$. The arousal effect of caffeine was recently shown to be dependent on the $\mathrm{A}_{2 \mathrm{~A}} \mathrm{AR}^{105}$. However, the locomotor stimulatory effect of high doses of caffeine is not the result of the blockade of either the $\mathrm{A}_{1} \mathrm{AR}$ or the $\mathrm{A}_{2 \mathrm{~A}} \mathrm{AR}$, and an effect that is independent of AR activity is probable ${ }^{104}$. Although the concept of using AR agonists as modulators for sleep disorders is intriguing, in practice this would be dependent on brainselective receptor activation.

\section{Other potential applications}

Adenosine is important in mediating at least some of the neuronal responses to ethanol ${ }^{149,150}$. Ethanol increases brain levels of adenosine by inhibiting adenosine reuptake, which activates $\mathrm{A}_{2 \mathrm{~A}} \mathrm{ARs}$ and thereby raises cAMP concentrations. The resulting activation of protein kinase A leads to activation of cAMP response element (CRE)-mediated gene expression. Alcohol and adenosine therefore interact synergistically with the activation of $\mathrm{D}_{2} \mathrm{Rs}$ in median spiny neurons of the striatum/nucleus accumbens, unlike the otherwise antagonistic relationship between dopamine and adenosine. This is thought to involve the Gprotein $\beta, \gamma$ dimers, the inhibition of which reduces voluntary alcohol consumption. Therefore, drugs that antagonize the synergism of $\mathrm{A}_{2 \mathrm{~A}} \mathrm{AR}$ and $\mathrm{D}_{2} \mathrm{R}$ effects might be useful in controlling alcohol abuse.

There has also been recent progress in the imaging of ARs in the brain. An ${ }^{18} \mathrm{~F}$ analogue of DPCPX has been developed as a positron-emission tomographic imaging agent ${ }^{151}$. The highly potent and selective $\mathrm{A}_{2 \mathrm{~A}} \mathrm{AR}$ antagonist $\mathrm{SCH} 442416$ in ${ }^{11} \mathrm{C}$-labelled form has been established as an in vivo receptor-imaging agent in the rat and primate brain, which may eventually strengthen the link between the $\mathrm{A}_{2 \mathrm{~A}} \mathrm{AR}$ and disease states, as well as aid in identifying those patients that are likely to benefit from adenosine-related therapeutics ${ }^{152}$.

Finally, blockade of $\mathrm{A}_{2 \mathrm{~A}} \mathrm{AR}$ has a clear antidepressant effect ${ }^{153}$, suggesting that selective $\mathrm{A}_{2 \mathrm{~A}} \mathrm{AR}$ antagonists could be pursued as antidepressant drugs. $\mathrm{A}_{1} \mathrm{AR}$ activation has also been a target in the development of antiepileptic therapy ${ }^{6}$, and an inhibitor of adenosine kinase was shown to inhibit seizure activity in animals ${ }^{6}$.

\section{ARs as targets in renal system disorders}

Activation of $A_{1} A R$ protected against ischaemia- reperfusion-induced kidney injury ${ }^{154}$. Pretreatment of C57BL/6 mice with an $\mathrm{A}_{1} \mathrm{AR}$ antagonist caused a significant deterioration in renal function ${ }^{154}$. In addition, $\mathrm{A}_{1} \mathrm{AR}$ expression protects renal proximal tubular epithelial cells against cisplatin-mediated apoptosis ${ }^{155}$. Mice lacking $\mathrm{A}_{1}$ ARs showed a completely blocked renal glomerular filtration rate by a tubuloglomerular feedback mechanism ${ }^{156,157}$, and $A_{1}$ AR-knockout mice had increased renal injury after ischaemia and reperfusion ${ }^{158}$. Therefore, the kidney protective effect of $\mathrm{A}_{1} \mathrm{AR}$ agonists has been evident, which provides the basis for their future development as drugs for the treatment of renal failure.

Unlike $\mathrm{A}_{1} \mathrm{AR}$ agonists, $\mathrm{A}_{1} \mathrm{AR}$ antagonists are effective diuretic agents that are useful in treating fluid-retention disorders, including congestive heart failure, although antagonism of $\mathrm{A}_{1} \mathrm{ARs}$ is potentially a concern when using these agents in patients with ischaemic heart and kidney injury. An $\mathrm{A}_{1}$ AR antagonist, BG9719 (CVT-124), was in Phase II clinical trials (now discontinued) for the treatment of acute renal disorders in patients with congestive heart failure ${ }^{159,160}$. However, BG9719 contains an epoxide group, which is potentially chemically reactive. However, a non-epoxide-containing antagonist in the same series, BG9928, 
improves renal function and congestive heart failure without exacerbating cardiac injury ${ }^{161}$. BG9928, now in Phase II clinical trials, was found to improve sodium excretion in heart failure patients.

$\mathrm{A}_{2 \mathrm{~A}} \mathrm{AR}$ agonist-mediated cellular protection is particularly evident in peripheral tissues, including the kidney ${ }^{2}$. The $\mathrm{A}_{2 \mathrm{~A}} \mathrm{AR}$ in bone marrow-derived cells is also responsible for protection against ischaemic injury in the kidney ${ }^{162}$. A recently developed $\mathrm{A}_{2 \mathrm{~A}} \mathrm{AR}$ agonist, ATL-146e, was shown to protect against ischaemic renal injury ${ }^{163}$, and the mixed $A_{1}$ / $\mathrm{A}_{2 \mathrm{~A}} \mathrm{AR}$ agonist AMP579 was initially tested in patients with end-stage renal insufficiency; however, further clinical testing of the compound is impossible due to its inhibition of HERG channels ${ }^{164}$.

The expression of the A AR in the kidney ${ }^{165} 2 \mathrm{~B}$ and the presence of endogenous $\mathrm{A}_{2 \mathrm{~B}} \mathrm{ARs}$ in the HEK-293 cell line ${ }^{166}$ suggested a potential role in the kidney for this subtype, which is known to regulate cell growth and pro-liferation ${ }^{167}$. Finally, mice lacking the $\mathrm{A}_{3} \mathrm{AR}$ or wildtype mice in which the $\mathrm{A}_{3} \mathrm{AR}$ was blocked pharmacologically had significant renal protection ${ }^{168}$, suggesting that $\mathrm{A}_{3} \mathrm{AR}$ antagonists might have general renal-protective properties. Recent evidence suggested that both $\mathrm{A}_{1} \mathrm{AR}$ agonists and $\mathrm{A}_{3} \mathrm{AR}$ antagonists protect the kidney. Ligands possessing dual acting and opposite properties at these AR subtypes could therefore be effective therapeutic agents for renal protection.

\section{ARs as targets in pulmonary disorders}

A protective role for the $A_{1} A R$ in adenosine-dependent pulmonary injury has been proposed $^{169}$. Genetic removal of the $A_{1} A R$ from adenosine deaminase-deficient mice caused enhanced pulmonary inflammation along with increased mucus metaplasia and alveolar destruction. The expression of $\mathrm{T}_{\mathrm{H}} 2$ cytokines interleukin-4 (IL-4) andIL-13 in the lungs, as well as chemokines and matrix metalloproteinases, was upregulated. These findings imply that $\mathrm{A}_{1} \mathrm{AR}$ agonists have potential for the therapeutic treatment of pulmonary injury.

In the asthmatic lung, adenosine acts as an irritant and bronchoconstrictor, and so a synthetic $\mathrm{AR}$ antagonist, perhaps selective for the $\mathrm{A}_{2 \mathrm{~B}} \mathrm{AR}$, could have therapeutic potential in asthma treatment ${ }^{170}$. In mouse mast cells, $\mathrm{A}_{3} \mathrm{AR}$ activation has been shown to induce mast-cell degranulation ${ }^{171}$. It has been suggested that this effect is mediated by the $\mathrm{A}_{2 \mathrm{~B}} \mathrm{AR}$ in human and canine mast cells $\mathrm{s}^{172-174}$. A bioavailable thiazole derivative that acts as a mixed antagonist at $\mathrm{A}_{2 \mathrm{~B}}$ and $\mathrm{A}_{3}$ ARs has been proposed to be a candidate therapeutic agent for the treatment of asthma ${ }^{175}$; however, this has not been tested in animal models. In addition, the bronchodilating, anti-asthmatic effects of theophylline and other xanthines might involve $\mathrm{A}_{2 \mathrm{~B}} \mathrm{AR}$ blockade, although the evidence for this is controversial due to the lack of an adequate animal model. The lack of $A_{2 B} A R$-selective agonists and, until recently, $A_{2 B} A R-$ knockout mice have hampered further clarification of the functional significance of this receptor.

Activation of the $\mathrm{A}_{2 \mathrm{~A}} \mathrm{AR}$ by CGS21680 produces broad-spectrum anti-inflammatory activity in a model of allergic asthma in the Brown Norway rat, suggesting that $\mathrm{A}_{2 \mathrm{~A}} \mathrm{AR}$ agonists could be useful alternatives to glucocor-ticosteroids in the treatment of asthma ${ }^{176}$. GW328267, an $\mathrm{A}_{2 \mathrm{~A}} \mathrm{AR}$ agonist designed for intranasal administration, was also evaluated in Phase II clinical trials for upper respiratory inflammatory disease, chronic obstructive pulmonary disease and asthma; however, the results at the dose used were negative and the compound has been withdrawn from clinical testing ${ }^{177}$. 
In preclinical testing, the $\mathrm{A}_{3} \mathrm{AR}$ agonist IB-MECA was shown to protect against lung injury and apoptosis in cats after reperfusion ${ }^{178}$, and this protection was antagonized by MRS1191, a dihydropyridine that is a selective A AR antagonist ${ }^{56}$

As described earlier, prominent species differences in the structure and function of ARs, especially the $\mathrm{A}_{3} \mathrm{AR}$, have been observed. For example, human and rat $\mathrm{A}_{3} \mathrm{ARs}$ only share $72 \%$ overall identity at the amino-acid level; mast-cell degranulation is induced by the $\mathrm{A}_{2 \mathrm{~B}} \mathrm{AR}$ in dogs and humans, but by the $\mathrm{A}_{3} \mathrm{AR}$ in mice. It is therefore plausible that some of the functions observed with one animal model might not be obtained in other animal models and in humans. Cross-species testing systems are necessary to validate the receptor function or effects of agonists and antagonists.

\section{ARs as targets in inflammatory disorders}

Adenosine-mediated activation of the $\mathrm{A}_{2 \mathrm{~A}} \mathrm{AR}$, which is found in almost all immune cells, including lymphocytes, monocytes, macrophages and dendritic cells ${ }^{179}$, seems to attenuate inflammation and reperfusion injury in a variety of tissues. Through $\mathrm{A}_{2 \mathrm{~A}} \mathrm{AR}$ activation, adenosine can inhibit T-cell activation, proliferation and production of inflammatory cytokines while enhancing the production of anti-inflammatory cytokines. Activation of the $\mathrm{A}_{2 \mathrm{~A}} \mathrm{AR}$ in $\mathrm{T}_{\mathrm{H}}$ and cytotoxic $\mathrm{T}$ lymphocytes directly inhibits IL-2secretion in vitro and IL-2driven expansion in vivo ${ }^{180}$. In murine $\mathrm{CD}^{+} \mathrm{T}$ cells, the $\mathrm{A}_{2 \mathrm{~A}} \mathrm{AR}$ agonists ATL-146e and ATL-313 were shown to reduce T cell-receptor (TCR)-mediated production of interferon- $\gamma$ (IFN $\gamma$ ). Rapid-induction TCR signalling of the mRNA for the $\mathrm{A}_{2 \mathrm{~A}} \mathrm{AR}$ suggests that this is a mechanism for limiting T-cell activation and secondary macrophage activation in inflamed tissues $^{181}$.

Ohta and Sitkovsky ${ }^{182}$ reported that $\mathrm{A}_{2 \mathrm{~A}} \mathrm{ARs}$ are crucially involved in the limitation and termination of prolonged inflammation. Knockout of the $\mathrm{A}_{2 \mathrm{~A}} \mathrm{AR}$ in mice showed that no other mechanism for inflammation could compensate fully for the loss of the $\mathrm{A}_{2 \mathrm{~A}} \mathrm{AR}$ (which has been referred to as a brake for inflammation ${ }^{183}$ ) on immune cells. Interestingly, in knockout mouse models, the $\mathrm{A}_{2 \mathrm{~A}} \mathrm{AR}$ together with the $\mathrm{A}_{3} \mathrm{AR}$ mediated the antiinflammatory effect of methotrexate, which is used as a treatment of arthritis ${ }^{184}$. ATL-146e, a selective agonist of the $\mathrm{A}_{2 \mathrm{~A}} \mathrm{AR}$, profoundly protects mouse liver from reperfusion injury, and the protection is blocked by the $\mathrm{A}_{2 \mathrm{~A}} \mathrm{AR}$ antagonist ZM241385. In mice lacking the $\mathrm{A}_{2 \mathrm{~A}} \mathrm{AR}$, protection by ATL-146e is lost and ischaemic injury of short duration is exacerbated, which contrasts with the results obtained in wild-type mice, suggesting a protective role for endogenous adenosine ${ }^{185}$. The $\mathrm{A}_{2 \mathrm{~A}} \mathrm{AR}$ agonist ATL-146e is also of interest for the treatment of sepsis ${ }^{186}$, inflammatory bowel disease ${ }^{187}$ and for inclusion in drug-eluting stents to prevent restenosis after angioplasty. Selective activation of the $\mathrm{A}_{2 \mathrm{~A}} \mathrm{AR}$ has also been shown to reduce skin pressure, ulcer formation and inflammation ${ }^{188}$, and wound healing is accelerated ${ }^{189}$.

The $\mathrm{A}_{3} \mathrm{AR}$ has been implicated in mediating allergic responses in mice; it facilitates the release of allergic mediators, such as histamine, in mast cells ${ }^{190}$. Systemic infusion of IBMECA causes scratching in mice that is prevented by co-administration of histamine antagonists ${ }^{142}$. The potentiation by Cl-IB-MECA of antigen-dependent degranulation of mast cells, as measured by hexosaminidase release, was lost in mice lacking $\mathrm{A}_{3} \mathrm{ARs}^{171}$. Attenuation of lipopolysaccharide-induced tumour-necrosis factor-a (TNFa) production was lower in mice lacking the $\mathrm{A}_{3} \mathrm{AR}$ than in control mice ${ }^{171}$.

Finally, adenosine has been implicated in arthritis treatment, and the possibility of administration of $A_{2 A} A R$ agonists for this purpose remains open ${ }^{191}$. The $A_{3} A R$ agonist IBMECA also showed beneficial effects in early human trials ${ }^{192}$. 


\section{ARs as targets for endocrine disorders}

$\mathrm{A}_{1} \mathrm{AR}$ agonists are under consideration as therapeutic candidates for obesity-related insulin resistance and type 2 diabetes ${ }^{193}$. In mice overexpressing the $A_{1} A R$ in adipose tissue, lower concentrations of plasma free fatty acids were observed than in litter-matched controls, and the transgenic mice did not develop insulin resistance. This supports a significant physiological role for adipocyte $\mathrm{A}_{1} \mathrm{AR}$ in the control of lipolysis. GR79236 has been tested in humans for adjuvant therapy in insulin resistance (type 2 diabetes). This $\mathrm{A}_{1} \mathrm{AR}$ agonist ameliorates the hypertriglyceridaemia induced by fructose feeding, and the reduction in fatty acid levels is associated with secondary improvements in glucose tolerance.

$\mathrm{A}_{2 \mathrm{~B}} \mathrm{AR}$ antagonists are also under consideration for diabetes treatment. A 2-alkynyl-8aryl-9-methyladenine derivative developed by Eisai showed hypoglycaemic activity in an animal model of type 2 diabetes, suggesting that adenosine agonist-induced glucose production in rat hepatocytes is mediated through the $A_{2 B} A R^{194}$. The $A_{2 A} A R$ agonist MRE-0094 is in Phase I clinical trials as a treatment for chronic diabetic neuropathic foot ulcers due to the anti-inflammatory and wound healing effects of $\mathrm{A}_{2 \mathrm{~A}} \mathrm{AR}$ agonists.

\section{ARs as targets in cancer}

$\mathrm{A}_{3} \mathrm{AR}$ agonists can induce or attenuate apoptosis depending on the range of agonist concentrations used, which might have important implications for their therapeutic use in disorders in which the aim is to either attenuate apoptosis, such as arthritis (see above), or induce it, as in cancer. In human eosinophils and human promyelocytic HL-60 cells ${ }^{195,196}$ the $\mathrm{A}_{3} \mathrm{AR}$ agonist $\mathrm{Cl}$-IB-MECA seems to induce apoptosis at relatively high concentrations $(>10 \mu \mathrm{M})$, but in RBL-2H3 cells, a lower concentration $(1 \mu \mathrm{M})$ of the $\mathrm{A}_{3} \mathrm{AR}$ agonist IBMECA block apoptosis that is induced by ultraviolet irradiation ${ }^{197}$.

A role for the $A_{3} A R$ in mediating control of the cell cycle has been reported ${ }^{198}$. Activation of the $\mathrm{A}_{3} \mathrm{AR}$ by adenosine triggers a cell survival response; by contrast, activation of $\mathrm{A}_{2 \mathrm{~A}} \mathrm{ARs}$ induces an apoptotic signalling pathway that involves protein kinase $\mathrm{C}$ and MAPKs ${ }^{199}$. Overexpression of the $A_{3} A R$ in transgenic mice resulted in embryonic lethality ${ }^{141}$, suggesting the possible use of selective $\mathrm{A}_{3} \mathrm{AR}$ agonists in anticancer therapy.

$\mathrm{A}_{3} \mathrm{AR}$ activation has been implicated in inhibition of tumour growth both in vitro and in $v i v o^{200}$, and IB-MECA is in clinical trials for colon carcinoma. However, the novel anticancer effect discovered by Fishman and colleagues is caused by a cytostatic effect on tumours related to the WNT pathway ${ }^{32}$, rather than by induction of apoptosis. Recently, it was shown that the $\mathrm{A}_{3} \mathrm{AR}$ is more highly expressed in tumour than in normal cells, which may justify $\mathrm{A}_{3} \mathrm{AR}$ as a potential target for tumour growth inhibition ${ }^{201}$. In human breast cancer cell lines, IB-MECA downregulated the oestrogen receptor and completely inhibited cell growth ${ }^{202}$.

\section{ARs as targets in visual disorders}

The $A_{3}$ AR-knockout mouse had significantly lower intraocular pressure, suggesting that $\mathrm{A}_{3} \mathrm{AR}$ antagonists have potential in the treatment of glaucoma ${ }^{203}$. Most reported $\mathrm{A}_{3} \mathrm{AR}$ antagonists are selective only at the human $\mathrm{A}_{3} \mathrm{AR}$, and so are not suitable for use in rodent models, but the selective $\mathrm{A}_{3} \mathrm{AR}$ antagonist OT-7999 reduced intraocular pressure in the monkey ${ }^{204}$. Encouragingly, the cross-species $\mathrm{A}_{3}$ AR antagonist MRS1292 was recently found to reduce mouse intraocular pressure and also inhibited adenosine-triggered human non-pigmented ciliary epithelial cell fluid release ${ }^{60}$. 


\section{Conclusions}

The medicinal chemistry of ARs is well developed, and selective agonists and antagonists have been generated for most of the receptor subtypes. In addition to the potential of directly acting orthosteric ligands, allosteric modulation of ARs is a promising approach. The application of genetic therapy with neoceptors could also potentially achieve organ or tissue selectivity in the future (BOX 1). With suitable pharmacological probes and the availability of knockout mice for three of the four subtypes, the basic science of ARs has progressed to the identification of novel therapeutic targets (FIG. 7). It is hoped that new agents in development will avoid the undesirable side effects that have impeded the clinical development of AR ligands in the past. Selective agonists are well advanced in clinical trials for the treatment of atrial fibrillation, pain, neuropathy, pulmonary and other inflammatory conditions, and cancer. Selective antagonists have entered clinical trials for the treatment of Parkinson's disease and congestive heart failure. Both in the case of diseases such as stroke, where there is an unmet medical need, and for diseases that already have pharmacological intervention options, the introduction of adenosine-based drug therapy will provide novel mechanisms for therapy. With the maturing of AR science, it is time for some of the myriad of selective agents synthesized to be implemented in the fight to improve human health.

\section{Glossary}

Angiogenesis

Allosteric site

Pertussis toxin

Bradycardiac effect

Mast cell

Photoisomerization

Paroxysmal supraventricular tachycardia (PSVT)

Atrial fibrillation

Dromotropic

Discriminative stimulus

$\mathbf{T}_{\mathbf{H}} \mathbf{2}$ cytokines
The growth of new blood vessels - for example, in pathology, the generation of a blood supply to a tumour.

A modulatory binding site on a receptor that is topographically distinct from the agonist binding site.

A compound that inhibits the guanine nucleotide binding proteins $G_{i}$ and $G_{0}$ via ADP-ribosylation.

An arrhythmia typified by an abnormally slow heart rate.

A type of leukocyte that has large secretory granules that contain histamine and various protein mediators.

A conversion between structural isomers caused by lightinduced excitation.

A regular, abnormally fast heart beat caused by rapid firing of electrical impulses from a focus above the AV (atrioventricular) node.

A condition in which disorganized electrical conduction in the atrial walls results in ineffective pumping of blood into the ventricle and an irregular heart rhythm.

Refers to velocity of AV nodal conduction in the heart.

In instrumental conditioning, the external stimulus that signals a particular relationship between the instrumental response and the reinforcer.

Cytokines such as interleukin (IL)-3, -4, -5, -6, -10 and -12 secreted by $\mathrm{T}_{\mathrm{H}} 2$ helper $\mathrm{T}$ lymphocytes to control various aspects of the antibody response. 


\section{Bioavailability}

\section{Somnogenic}

The fraction or percentage of an administered drug or other substance that becomes available to the target tissue after administration.

Sleep-inducing

\section{References}

1. Fredholm BB, IJzerman AP, Jacobson KA, Klotz KN, Linden J. International Union of Pharmacology. XXV. Nomenclature and classification of adenosine receptors. Pharmacol. Rev. 2001; 53:527-552. [PubMed: 11734617] A publication on AR nomenclature, structure, function and regulation by members of NC-IUPHAR subcommittee.

2. Linden J. Adenosine in tissue protection and tissue regeneration. Mol. Pharmacol. 2005; 67:13851387. [PubMed: 15703375] Summarizes four modes of adenosine's tissue protective action.

3. McGaraughty S, Cowart M, Jarvis MF, Berman RF. Anticonvulsant and antinociceptive actions of novel adenosine kinase inhibitors. Curr. Top. Med. Chem. 2005; 5:43-58. [PubMed: 15638777]

4. Zimmermann H. Extracellular metabolism of ATP and other nucleotides. Naunyn Schmiedebergs Arch. Pharmacol. 2000; 362:299-309. [PubMed: 11111825]

5. Pascual O, et al. Astrocytic purinergic signalling coordinates synaptic networks. Science. 2005; 310:113-116. [PubMed: 16210541]

6. Parkinson FE, Xiong W, Zamzow CR. Astrocytes and neurons: different roles in regulating adenosine levels. Neurol. Res. 2005; 27:153-160. [PubMed: 15829178]

7. Gao ZG, Kim SK, IJzerman AP, Jacobson KA. Allosteric modulation of the adenosine family of receptors. Mini Rev. Med. Chem. 2005; 5:545-553. [PubMed: 15974932]

8. van Calker D, Muller M, Hamprecht B. Adenosine regulates via two different types of receptors, the accumulation of cyclic AMP in cultured brain cells. J. Neurochem. 1979; 33:999-1005. [PubMed: 228008]

9. Londos C, Cooper DM, Wolff J. Subclasses of external adenosine receptors. Proc. Natl Acad. Sci. USA. 1980; 77:2551-2554. [PubMed: 6248853]

10. Tawfik HE, Schnermann J, Oldenburg PJ, Mustafa SJ. Role of $A_{1}$ adenosine receptors in the regulation of vascular tone. Am. J. Physiol. Heart Circ. Physiol. 2005; 288:H1411-H1416. [PubMed: 15539423]

11. Rogel A, Bromberg Y, Sperling O, Zoref-Shani E. Phospholipase C is involved in the adenosineactivated signal transduction pathway conferring protection against iodoacetic acid-induced injury in primary rat neuronal cultures. Neurosci. Lett. 2005; 373:218-221. [PubMed: 15619546]

12. Belardinelli L, Shryock JC, Song Y, Wang D, Srinivas M. Ionic basis of the electrophysiological actions of adenosine on cardiomyocytes. FASEB J. 1995; 9:359-365. [PubMed: 7896004]

13. Reid EA, et al. In vivo adenosine receptor preconditioning reduces myocardial infarct size via subcellular ERK signalling. Am. J. Physiol. Heart Circ. Physiol. 2005; 288:H2253-H2259. [PubMed: 15653762]

14. Kull B, Svenningsson P, Fredholm BB. Adenosine $A_{2 A}$ receptors are colocalized with and activate $\mathrm{G}_{\text {olf }}$ in rat striatum. Mol. Pharmacol. 2000; 58:771-777. [PubMed: 10999947]

15. Fresco P, Diniz C, Goncalves J. Facilitation of noradrenaline release by activation of adenosine $\mathrm{A}_{2 \mathrm{~A}}$ receptors triggers both phospholipase $\mathrm{C}$ and adenylate cyclase pathways in rat tail artery. Cardiovasc. Res. 2004; 63:739-746. [PubMed: 15306230]

16. Offermanns $S$, Simon MI. $G_{a 15}$ and $G_{a 16}$ couple a wide variety of receptors to phospholipase $C$. J. Biol. Chem. 1995; 270:15175-15180. [PubMed: 7797501]

17. Daly JW, Butts-Lamb P, Padgett W. Subclasses of adenosine receptors in the central nervous system: interaction with caffeine and related methylxanthines. Cell. Mol. Neurobiol. 1983; 3:6980. [PubMed: 6309393]

18. Brackett LE, Daly JW. Functional characterization of the $A_{2 B}$ adenosine receptor in NIH 3 T3 fibroblasts. Biochem. Pharmacol. 1994; 47:801-814. [PubMed: 8135856] 
19. Peakman MC, Hill SJ. Adenosine $\mathrm{A}_{2 \mathrm{~B}}$-receptor-mediated cyclic AMP accumulation in primary rat astrocytes. Br. J. Pharmacol. 1994; 111:191-198. [PubMed: 8012696]

20. Feoktistov I, Biaggioni I. Adenosine $A_{2 B}$ receptors evoke interleukin- 8 secretion in human mast cells. An enprofylline-sensitive mechanism with implications for asthma. J. Clin. Invest. 1995; 96:1979-1986. [PubMed: 7560091]

21. Gao Z, Chen T, Weber MJ, Linden J. $\mathrm{A}_{2 \mathrm{~B}}$ adenosine and $\mathrm{P} 2 \mathrm{Y}_{2}$ receptors stimulate mitogenactivated protein kinase in human embryonic kidney-293 cells. Cross-talk between cyclic AMP and protein kinase C pathways. J. Biol. Chem.. 1999; 274:5972-5980.

22. Linden J, Thai T, Figler H, Jin X, Robeva AS. Characterization of human $A_{2 B}$ adenosine receptors: radioligand binding, western blotting, and coupling to $\mathrm{G}_{\mathrm{q}}$ in human embryonic kidney 293 cells and HMC-1 mast cells. Mol. Pharmacol. 1999; 56:705-713. [PubMed: 10496952]

23. Donoso MV, Lopez R, Miranda R, Briones R, Huidobro-Toro JP. $\mathrm{A}_{2 \mathrm{~B}}$ adenosine receptor mediates human chorionic vasoconstriction and signals through the arachidonic acid cascade. Am. J. Physiol. Heart Circ. Physiol. 2005; 288:H2439-H2449. [PubMed: 15637124]

24. Zhou QY, et al. Molecular cloning and characterization of an adenosine receptor: the $A_{3}$ adenosine receptor. Proc. Natl Acad. Sci. USA. 1992; 89:7432-7436. [PubMed: 1323836]

25. Abbracchio MP, et al. G protein-dependent activation of phospholipase $\mathrm{C}$ by adenosine $\mathrm{A}_{3}$ receptors in rat brain. Mol. Pharmacol. 1995; 48:1038-1045. [PubMed: 8848003]

26. Shneyvays $\mathrm{V}$, et al. Role of adenosine $\mathrm{A}_{1}$ and $\mathrm{A}_{3}$ receptors in regulation of cardiomyocyte homeostasis after mitochondrial respiratory chain injury. Am. J. Physiol. Heart Circ. Physiol. 2005; 288:H2792-H2801. [PubMed: 15681707]

27. Englert M, Quitterer U, Klotz KN. Effector coupling of stably transfected human $\mathrm{A}_{3}$ adenosine receptors in CHO cells. Biochem. Pharmacol. 2002; 64:61-65. [PubMed: 12106606]

28. Fossetta $\mathbf{J}$, et al. Pharmacological analysis of calcium responses mediated by the human $\mathrm{A}_{3}$ adenosine receptor in monocyte-derived dendritic cells and recombinant cells. Mol. Pharmacol. 2003; 63:342-350. [PubMed: 12527805]

29. Shneyvays V, Zinman T, Shainberg A. Analysis of calcium responses mediated by the $\mathrm{A}_{3}$ adenosine receptor in cultured newborn rat cardiac myocytes. Cell Calcium. 2004; 36:387-396. [PubMed: 15451622]

30. Tracey WR, Magee W, Masamune H, Oleynek JJ, Hill RJ. Selective activation of adenosine $\mathrm{A}_{3}$ receptors with $N^{6}$-(3-chlorobenzyl)-5' $-N$-methylcarbox-amidoadenosine (CB-MECA) provides cardioprotection via $\mathrm{K}_{\mathrm{ATP}}$ channel activation. Cardiovasc. Res. 1998; 40:138-145. [PubMed: 9876326]

31. Mozzicato S, Joshi BV, Jacobson KA, Liang BT. Role of direct RhoA-phospholipase D1 interaction in mediating adenosine-induced protection from cardiac ischemia. FASEB J. 2004; 18:406-408. [PubMed: 14688204]

32. Fishman $\mathrm{P}$, et al. Evidence for involvement of Wnt signalling pathway in IB-MECA mediated suppression of melanoma cells. Oncogene. 2002; 21:4060-4064. [PubMed: 12037688]

33. Schulte G, Fredholm BB. Signalling pathway from the human adenosine $A_{3}$ receptor expressed in Chinese hamster ovary cells to the extracellular signal-regulated kinase $1 / 2$. Mol. Pharmacol. 2002; 62:1137-1146. [PubMed: 12391277]

34. Schulte G, Fredholm BB. Signalling from adenosine receptors to mitogen-activated protein kinases. Cell Signal. 2003; 15:813-827. [PubMed: 12834807] Reports that each of the four ARs can activate one or more of the MAPKs by substantially different mechanisms.

35. Merighi $\mathrm{S}$, et al. $\mathrm{A}_{3}$ adenosine receptor activation inhibits cell proliferation via phosphatidylinositol 3-kinase (PI3K)/AKT-dependent inhibition of the extracellular signalregulated kinase (ERK)1/2 phosphorylation in A375 human melanoma cells. J. Biol. Chem. 2005; 280:19516-19526. [PubMed: 15774470]

36. Olah ME, Stiles GL. The role of receptor structure in determining adenosine receptor activity. Pharmacol. Ther. 2000; 85:55-75. [PubMed: 10722120]

37. Yan L, Burbiel JC, Maass A, Müller CE. Adenosine receptor agonists: from basic medicinal chemistry to clinical development. Expert Opin. Emerging Drugs. 2003; 8:537-576.

38. Kim SK, et al. Modelling the adenosine receptors: Comparison of binding domains of $\mathrm{A}_{2 \mathrm{~A}}$ agonist and antagonist. J. Med. Chem. 2003; 46:4847-4859. [PubMed: 14584936] 
39. Tchilibon $\mathrm{S}$, et al. (N)-Methanocarba-2, $N^{6}$-disubstituted adenine nucleosides as highly potent and selective $\mathrm{A}_{3}$ adenosine receptor agonists. J. Med. Chem. 2005; 48:1745-1758. [PubMed: 15771421]

40. Moro S, Gao ZG, Jacobson KA, Spalluto G. Progress in pursuit of therapeutic adenosine receptor antagonists. Med. Res. Rev. 2006; 26:131-159. [PubMed: 16380972] Summary of the most recent progress in developing new therapeutic AR antagonists.

41. Moro S, Bacillieri M, Cacciari B, Spalluto G. Autocorrelation of molecular electrostatic potential surface properties combined with partial least squares analysis as new strategy for the prediction of the activity of human $\mathrm{A}_{3}$ adenosine receptor antagonists. J. Med. Chem. 2005; 48:5698-5704. [PubMed: 16134938]

42. Gao ZG, et al. Structural determinants of $\mathrm{A}_{3}$ adenosine receptor activation: Nucleoside ligands at the agonist/antagonist boundary. J. Med. Chem. 2002; 45:4471-4484. [PubMed: 12238926]

43. Gao ZG, Blaustein J, Gross AS, Melman N, Jacobson KA. $N^{6}$-Substituted adenosine derivatives: selectivity, efficacy, and species differences at $\mathrm{A}_{3}$ adenosine receptors, Biochem. Pharmacol. 2003; 65:1675-1684.

44. Martin PL, Wysocki RJ Jr, Barrett RJ, May JM, Linden J. Characterization of 8- $(N-$ methylisopropyl)amino- $N^{6}$-( $5^{\prime}$-endohydroxy-endonorbornyl)-9-methyladenine (WRC-0571), a highly potent and selective, non-xanthine antagonist of $\mathrm{A}_{1}$ adenosine receptors. J. Pharmacol. Exp. Ther. 1996; 276:490-499. [PubMed: 8632314]

45. Rieger JM, Brown ML, Sullivan GW, Linden J, MacDonald TL. Design, synthesis, and evaluation of novel adenosine $A_{2 A}$ receptor agonists. J. Med. Chem. 2001; 44:531-539. [PubMed: 11170643]

46. Bridges AJ, et al. $N^{6}$-[2-(3, 5-dimethoxyphenyl)-2-(2-methylphenyl)ethyl]adenosine and its uronamide derivatives. Novel adenosine agonists with both high affinity and high selectivity for the adenosine $A_{2}$ receptor. J. Med. Chem. 1988; 31:1282-1285. [PubMed: 3385722]

47. Palmer TM, Poucher SM, Jacobson KA, Stiles GL. ${ }^{125}$ I-4-(2-[7-Amino-2- $\{$ furyl $\}$ $\{1,2,4\}$ triazolo $\{2,3-\mathrm{a}\}\{1,3,5\}$ triazin-5-ylaminoethyl)phenol ( $\left.{ }^{125} \mathrm{I}-\mathrm{ZM} 241385\right)$, a high affinity antagonist radioligand selective for the $\mathrm{A}_{2 \mathrm{~A}}$ adenosine receptor. Mol. Pharmacol. 1996; 48:970 974. [PubMed: 8848012]

48. Baraldi PG, et al. Design, synthesis, and biological evaluation of a second generation of pyrazolo[4,3-e]1, 2,4-triazolo[1,5-c]pyrimidines as potent and selective $\mathrm{A}_{2 \mathrm{~A}}$ adenosine receptor antagonists. J. Med. Chem. 1998; 41:2126-2133. [PubMed: 9622554]

49. Ji XD, Jacobson KA. $\left[{ }^{3} \mathrm{H}\right]-\mathrm{ZM} 241385$ as a radioligand at recombinant human $\mathrm{A}_{2 \mathrm{~B}}$ adenosine receptors. Drug Des. Discov. 1999; 16:217-226. [PubMed: 10624567]

50. Kase $\mathrm{H}$, et al. Progress in pursuit of therapeutic $\mathrm{A}_{2 \mathrm{~A}}$ antagonists: the adenosine $\mathrm{A}_{2 \mathrm{~A}}$ receptor selective antagonist KW6002: research and development toward a novel nondopaminergic therapy for Parkinson's disease. Neurology. 2003; 61:S97-S100. [PubMed: 14663020]

51. Volpini R, Costanzi S, Vittori S, Cristalli G, Klotz KN. Medicinal chemistry and pharmacology of $\mathrm{A}_{2 \mathrm{~B}}$ adenosine receptors. Curr. Top. Med. Chem. 2003; 3:427-443. [PubMed: 12570760]

52. Beukers MW, et al. New, non-adenosine, highpotency agonists for the human adenosine $\mathrm{A}_{2 \mathrm{~B}}$ receptor with an improved selectivity profile compared to the reference agonist $\mathrm{N}$ ethylcarboxamido-adenosine. J. Med. Chem. 2004; 47:3707-3709. [PubMed: 15239649] The first report of non-nucleoside agonists for the human $\mathrm{A}_{2 \mathrm{~B}} \mathrm{AR}$, with one of those compounds showing potency of about $10 \mathrm{nM}$.

53. Ji X, Kim YC, Ahern DG, Linden J, Jacobson KA. $\left[{ }^{3} \mathrm{H}\right] \mathrm{MRS}$ 1754, a selective antagonist radioligand for $\mathrm{A}_{2 \mathrm{~B}}$ adenosine receptors. Biochem. Pharmacol. 2001; 61:657-663. [PubMed: 11266650]

54. Gessi S, et al. Expression, pharmacological profile, and functional coupling of $\mathrm{A}_{2 \mathrm{~B}}$ receptors in a recombinant system and in peripheral blood cells using a novel selective antagonist radioligand, [ ${ }^{3}$ H]MRE 2029-F20. Mol. Pharmacol. 2005; 67:2137-2147. [PubMed: 15788741]

55. Stewart M, et al. $\left[{ }^{3} \mathrm{H}\right]$ OSIP339391, a selective, novel, and high affinity antagonist radioligand for adenosine A2B receptors. Biochem. Pharmacol. 2004; 68:305-312. [PubMed: 15194002]

56. Jacobson KA. $A_{3}$ adenosine receptors: novel ligands and paradoxical effects. Trends Pharmacol. Sci. 1998; 19:184-191. [PubMed: 9652191] 
57. Olah ME, Gallo-Rodriguez C, Jacobson KA, Stiles GL. ${ }^{125}$ I-4-Aminobenzyl-5' $-\mathrm{N}$-methylcarboxamidoadenosine, a high affinity radioligand for the rat $\mathrm{A}_{3}$ adenosine receptor. Mol. Pharmacol. 1994; 45:978-982. [PubMed: 8190112]

58. Jeong LS, et al. $N^{6}$-Substituted D- $4^{\prime}$-thioadenosine- $5^{\prime}$-methyluronamides: potent and selective agonists at the human $\mathrm{A}_{3}$ adenosine receptor. J. Med. Chem. 2003; 46:3775-3777. [PubMed: 12930138]

59. Linden J. Cloned adenosine $A_{3}$ receptors: pharmacological properties, species differences and receptor functions. Trends Pharmacol. Sci. 1994; 15:298-306. [PubMed: 7940998]

60. Yang H, et al. The cross-species $A_{3}$ adenosine-receptor antagonist MRS 1292 inhibits adenosinetriggered human nonpigmented ciliary epithelial cell fluid release and reduces mouse intraocular pressure. Curr. Eye Res. 2005; 30:747-754. [PubMed: 16146920] Application of the first rationally designed, cross-species, nucleoside antagonist in an animal model for antiglaucoma effects.

61. Müller CE, Diekmann M, Thorand M, Ozola V. $\left[{ }^{3} \mathrm{H}\right] 8$-Ethyl-4-methyl-2-phenyl-(8R)-4,5,7,8tetrahydro-1H-imidazo[2,1-i]-purin-5-one $\left(\left[{ }^{3} \mathrm{H}\right] \mathrm{PSB}-11\right)$, a novel high-affinity antagonist radioligand for human $\mathrm{A}_{3}$ adenosine receptors. Bioorg. Med. Chem. Lett. 2002; 12:501-503. [PubMed: 11814828]

62. Perreira M, et al. 'Reversine' and its 2-substituted adenine derivatives as potent and selective $\mathrm{A}_{3}$ adenosine receptor antagonists. J. Med. Chem. 2005; 48:4910-4918. [PubMed: 16033270]

63. Zablocki JA, Wu L, Shryock J, Belardinelli L. Partial $\mathrm{A}_{1}$ adenosine receptor agonists from a molecular perspective and their potential use as chronic ventricular rate control agents during atrial fibrillation (AF). Curr. Top. Med. Chem. 2004; 4:839-854. [PubMed: 15078215]

64. Fraser H, Gao Z, Ozeck MJ, Belardinelli L. N-[3-(R)-tetrahydrofuranyl]-6-aminopurine riboside, an $\mathrm{A}_{1}$ adenosine receptor agonist, antagonizes catecholamine-induced lipolysis without cardiovascular effects in awake rats. J. Pharmacol. Exp. Ther. 2003; 305:225-231. [PubMed: 12649373]

65. Bayes M, Rabasseda X, Prous JR. Gateways to clinical trials. Methods Find. Exp. Clin. Pharmacol. 2003; 25:831-855. [PubMed: 14735233]

66. Ellenbogen KA, et al. Trial to evaluate the management of paroxysmal supraventricular tachycardia during an electrophysiology study with tecadenoson. Circulation. 2005; 111:32023208. [PubMed: 15956124] Reports that the $\mathrm{A}_{1} \mathrm{AR}$ agonist, Tecadenoson, terminates paroxysmal supraventricular tachycardia without the clinically significant side effects caused by stimulation of other ARs.

67. Wagner H, et al. General pharmacology of SDZ WAG-994, a potent selective and orally-active adenosine $A_{1}$ receptor agonist. Drug Dev. Res. 1995; 34:276-288.

68. Auchampach JA, et al. Selective activation of $\mathrm{A}_{3}$ adenosine receptors with $N^{6}$-(3-iodobenzyl) adenosine- $5^{\prime}-N$-methyluronamide protects against myocardial stunning and infarction without hemodynamic changes in conscious rabbits. Circ. Res. 1997; 80:800-809. [PubMed: 9168782]

69. Schindler CW, et al. Role of central and peripheral adenosine receptors in the cardiovascular responses to intraperitoneal injections of adenosine $\mathrm{A}_{1}$ and $\mathrm{A}_{2 \mathrm{~A}}$ subtype receptor agonists. $\mathrm{Br}$. $\mathrm{J}$. Pharmacol. 2005; 144:642-650. [PubMed: 15678095]

70. Schulte $\mathrm{G}$, et al. Adenosine $\mathrm{A}_{1}$ receptors are necessary for protection of the murine heart by remote, delayed adaptation to ischaemia. Acta Physiol. Scand. 2004; 182:133-143. [PubMed: 15450109]

71. Matherne GP, Linden J, Byford AM, Gauthier NS, Headrick JP. Transgenic A 1 adenosine receptor overexpression increases myocardial resistance to ischemia. Proc. Natl Acad. Sci. USA. 1997; 94:6541-6546. [PubMed: 9177254]

72. Gauthier NS, Headrick JP, Matherne GP. Myocardial function in the working mouse heart overexpressing cardiac $A_{1}$ adenosine receptors. J. Mol. Cell. Cardiol. 1998; 30:187-193. [PubMed: 9500876]

73. Yang $\mathrm{Z}$, et al. Cardiac overexpression of $\mathrm{A}_{1}$-adenosine receptor protects intact mice against myocardial infarction. Am. J. Physiol. Heart Circ. Physiol. 2002; 282:H949-H955. [PubMed: 11834491] 
74. Headrick JP, Gauthier NS, Morrison R, Matherne GP. Cardioprotection by K(ATP) channels in wild-type hearts and hearts overexpressing $\mathrm{A}_{1}$-adenosine receptors. Am. J. Physiol. Heart Circ. Physiol. 2000; 279:H1690-H1697. [PubMed: 11009456]

75. Cerniway RJ, Yang Z, Jacobson MA, Linden J, Matherne GP. Targeted deletion of $A_{3}$ adenosine receptors improves tolerance to ischemia-reperfusion injury in mouse myocardium. Am. J. Physiol. Heart Circ. Physiol. 2001; 281:H1751-H1758. [PubMed: 11557567]

76. Joosen MJ, Bueters TJ, van Helden HP. Cardiovascular effects of the adenosine $\mathrm{A}_{1}$ receptor agonist $N^{6}$-cyclopentyladenosine (CPA) decisive for its therapeutic efficacy in sarin poisoning. Arch. Toxicol. 2004; 78:34-39. [PubMed: 14508639]

77. Reichelt ME, et al. Genetic deletion of the $\mathrm{A}_{1}$ adenosine receptor limits myocardial ischemic tolerance. Circ. Res. 2005; 96:363-367. [PubMed: 15653569]

78. Tracey WR, et al. Novel $N^{6}$-substituted adenosine $5^{\prime}-N$-methyluronamides with high selectivity for human adenosine $A_{3}$ receptors reduce ischemic myocardial injury. Am. J. Physiol. Heart Circ. Physiol. 2003; 285:H2780-H2787. [PubMed: 12919933]

79. Cross HR, Murphy E, Black RG, Auchampach J, Steenbergen C. Overexpression of $\mathrm{A}_{3}$ adenosine receptors decreases heart rate, preserves energetics, and protects ischemic hearts. Am. J. Physiol. Heart Circ. Physiol. 2002; 283:H1562-H1568. [PubMed: 12234810]

80. Black RG, et al. Gene dosage-dependent effects of cardiac-specific overexpression of the $\mathrm{A}_{3}$ adenosine receptor. Circ. Res. 2002; 91:165-172. [PubMed: 12142350]

81. Guo $\mathrm{Y}$, et al. Targeted deletion of the $\mathrm{A}_{3}$ adenosine receptor confers resistance to myocardial ischemic injury and does not prevent early preconditioning. J. Mol. Cell Cardiol. 2001; 33:825830. [PubMed: 11273734]

82. Harrison GJ, et al. Effects of $\mathrm{A}_{3}$ adenosine receptor activation and gene knock-out in ischemicreperfused mouse heart. Cardiovasc. Res. 2002; 53:147-155. [PubMed: 11744023]

83. Yang $\mathrm{Z}$, et al. Infarct sparing effect of $\mathrm{A}_{2 \mathrm{~A}}$-adenosine receptor activation is due primarily to its actions on lymphocytes. Circulation. 2005; 111:2190-2197. [PubMed: 15851591]

84. Gerlai R. Gene-targeting studies of mammalian behavior: is it the mutation or the background genotype? Trends Neurosci. 1996; 19:177-181. [PubMed: 8723200]

85. De Jonge R, Out M, Maas WJ, De Jong JW. Preconditioning of rat hearts by adenosine $\mathrm{A}_{1}$ or $\mathrm{A}_{3}$ receptor activation. Eur. J. Pharmacol. 2002; 441:165-172. [PubMed: 12063088]

86. Wang $J$, et al. Dual activation of adenosine $A_{1}$ and $A_{3}$ receptors mediates preconditioning of isolated cardiac myocytes. Eur. J. Pharmacol. 1997; 320:241-248. [PubMed: 9059860]

87. Shneyvays V, Mamedova L, Zinman T, Jacobson KA, Shainberg A. Activation of $\mathrm{A}_{3}$ adenosine receptor protects against doxorubicin-induced cardiotoxicity. J. Mol. Cell. Cardiol. 2001; 33:1249-1261. [PubMed: 11444927]

88. Varani K, et al. Dose and time effects of caffeine intake on human platelet adenosine $\mathrm{A}_{2 \mathrm{~A}}$ receptors: functional and biochemical aspects. Circulation. 2000; 102:285-289. [PubMed: 10899090]

89. Hendel RC, et al. Initial clinical experience with regadenoson, a novel selective $\mathrm{A}_{2 \mathrm{~A}}$ agonist for pharmacologic stress single-photon emission computed tomography myocardial perfusion imaging. J. Am. Coll. Cardiol. 2005; 46:2069-2075. [PubMed: 16325044]

90. Barrett RJ, Lamson MJ, Johnson J, Smith WB. Pharmacokinetics and safety of binodenoson after intravenous dose escalation in healthy volunteers. J. Nucl. Cardiol. 2005; 12:166-171. [PubMed: 15812370]

91. Rubino A, Ralevic V, Burnstock G. The P1-purinoceptors that mediate the prejunctional inhibitory effect of adenosine on capsaicin-sensitive nonadrenergic noncholinergic neurotransmission in the rat mesenteric arterial bed are of the $A_{1}$ subtype. J. Pharmacol. Exp. Ther. 1993; 267:1100-1104. [PubMed: 8263771]

92. Szentmiklosi AJ, et al. Adenosine receptors mediate both contractile and relaxant effects of adenosine in main pulmonary artery of guinea pigs. Naunyn. Schmiedebergs Arch. Pharmacol. 1995; 351:417-425. [PubMed: 7543187]

93. Eltzschig HK, et al. Coordinated adenine nucleotide phosphohydrolysis and nucleoside signalling in posthypoxic endothelium: role of ectonucleotidases and adenosine $\mathrm{A}_{2 \mathrm{~B}}$ receptors. J. Exp. Med. 2003; 198:783-796. [PubMed: 12939345] 
94. Dubey RK, Gillespie DG, Shue H, Jackson EK. A2B receptors mediate antimitogenesis in vascular smooth muscle cells. Hypertension. 2000; 35:267-272. [PubMed: 10642309]

95. Chen $\mathrm{Y}$, et al. Functional effects of enhancing or silencing adenosine $\mathrm{A}_{2 \mathrm{~B}}$ receptors in cardiac fibroblasts. Am. J. Physiol. Heart Circ. Physiol. 2004; 287:H2478-H2486. [PubMed: 15284071]

96. Matheson PJ, Spain DA, Harris PD, Garrison RN, Wilson MA. Glucose and glutamine gavage increase portal vein nitric oxide metabolite levels via adenosine $A_{2 B}$ activation. J. Surg. Res. 1999; 84:57-63. [PubMed: 10334890]

97. Feoktistov I, et al. Hypoxia modulates adenosine receptors in human endothelial and smooth muscle cells toward an $\mathrm{A}_{2 \mathrm{~B}}$ angiogenic phenotype. Hypertension. 2004; 44:649-654. [PubMed: $15452028]$ Description of the angiogenic role of the $A_{2 B} A R$ under hypoxic conditions.

98. Tilley SL, Wagoner VA, Salvatore CA, Jacobson MA, Koller BH. Adenosine and inosine increase cutaneous vasopermeability by activating $\mathrm{A}_{3}$ receptors on mast cells. J. Clin. Invest. 2000; 105:361-367. [PubMed: 10675362]

99. Zhao Z, Makaritsis K, Francis CE, Gavras H, Ravid K. A role for the $\mathrm{A}_{3}$ adenosine receptor in determining tissue levels of cAMP and blood pressure: studies in knock-out mice. Biochim. Biophys. Acta. 2000; 1500:280-290. [PubMed: 10699369]

100. Talukder MA, et al. Targeted deletion of adenosine $A_{3}$ receptors augments adenosine-induced coronary flow in isolated mouse heart. Am. J. Physiol. Heart Circ. Physiol. 2002; 282:H2183H2189. [PubMed: 12003827]

101. Jones MR, et al. A 3 adenosine receptor deficiency does not influence atherogenesis. J. Cell Biochem. 2004; 92:1034-1043. [PubMed: 15258925]

102. Solinas $M$, et al. Involvement of adenosine $A_{1}$ receptors in the discriminative-stimulus effects of caffeine in rats. Psychopharmacology (Berl.). 2005; 179:576-586. [PubMed: 15696333]

103. Ledent $\mathrm{C}$, et al. Aggressiveness, hypoalgesia and high blood pressure in mice lacking the adenosine $A_{2 A}$ receptor. Nature. 1997; 388:674-678. [PubMed: 9262401] The first demonstration of $A_{2 A}$ AR-mediated effects, such as pain, aggregation of platelets, hypertension and caffeine's stimulant effect, by using a receptor-knockout model.

104. Fredholm BB, Chen JF, Masino SA, Vaugeois JM. Actions of adenosine at its receptors in the CNS: insights from knockouts and drugs. Annu. Rev. Pharmacol. Toxicol. 2005; 45:385-412. [PubMed: 15822182] A thoughtful overview of the roles of ARs in CNS disorders.

105. Huang $\mathrm{ZL}$, et al. Adenosine $\mathrm{A}_{2 \mathrm{~A}}$, but not $\mathrm{A}_{1}$, receptors mediate the arousal effect of caffeine. Nature Neurosci. 2005; 8:858-859. [PubMed: 15965471] The authors used both $A_{1} A R-$ and $\mathrm{A}_{2 \mathrm{~A}} \mathrm{AR}$-knockout mice to show that the $\mathrm{A}_{2 \mathrm{~A}} \mathrm{AR}$, not the $\mathrm{A}_{1} \mathrm{AR}$, is crucial in caffeine-induced wakefulness.

106. Satoh S, Matsumura H, Hayaishi O. Involvement of adenosine $\mathrm{A}_{2 \mathrm{~A}}$ receptor in sleep promotion. Eur. J. Pharmacol. 1998; 351:155-162. [PubMed: 9686998]

107. Maemoto T, et al. Pharmacological characterization of FR194921, a new potent, selective, and orally active antagonist for central adenosine $A_{1}$ receptors. J. Pharmacol. Sci. 2004; 96:42-52. [PubMed: 15351792]

108. Sawynok J. Adenosine receptor activation and nociception. Eur. J. Pharmacol. 1998; 347:1-11. [PubMed: 9650842]

109. Johansson B, et al. Hyperalgesia, anxiety, and decreased hypoxic neuroprotection in mice lacking the adenosine $A_{1}$ receptor. Proc. Natl. Acad. Sci. USA. 2001; 98:9407-9412. [PubMed: 11470917] Initial study of $A_{1}$ AR-mediated CNS effect by using $A_{1}$ AR-knockout mice.

110. $\mathrm{Wu} \mathrm{WP}$, et al. Increased nociceptive response in mice lacking the adenosine $\mathrm{A}_{1}$ receptor. Pain. 2005; 113:395-404. [PubMed: 15661449]

111. Gordh T, Karlsten R, Kristensen J. Intervention with spinal NMDA, adenosine, and NO systems for pain modulation. Ann. Med. 1995; 27:229-234. [PubMed: 7632419]

112. Giffin NJ, et al. Effect of the adenosine $A_{1}$ receptor agonist GR79236 on trigeminal nociception with blink reflex recordings in healthy human subjects. Cephalalgia. 2003; 23:287-292. [PubMed: 12716347]

113. Zambrowicz BP, Turner CA, Sands AT. Predicting drug efficacy: knockouts model pipeline drugs of the pharmaceutical industry. Curr. Opin. Pharmacol. 2003; 3:563-570. [PubMed: 14559104] 
114. Li X, Conklin D, Pan HL, Eisenach JC. Allosteric adenosine receptor modulation reduces hypersensitivity following peripheral inflammation by a central mechanism. J. Pharmacol. Exp. Ther. 2003; 305:950-955. [PubMed: 12606636]

115. Ferre S, von Euler G, Johansson B, Fredholm BB, Fuxe K. Stimulation of high-affinity adenosine A2 receptors decreases the affinity of dopamine D2 receptors in rat striatal membranes. Proc. Natl Acad. Sci. USA. 1991; 88:7238-7241. [PubMed: 1678519]

116. Hillion J, et al. Coaggregation, cointernalization, and codesensitization of adenosine $\mathrm{A}_{2 \mathrm{~A}}$ receptors and dopamine $\mathrm{D}_{2}$ receptors. J. Biol. Chem. 2002; 277:18091-18097. [PubMed: 11872740]

117. Svenningsson P, Le Moine C, Fisone G, Fredholm BB. Distribution, biochemistry and function of striatal adenosine A2A receptors. Prog. Neurobiol. 1999; 59:355-396. [PubMed: 10501634]

118. Aoyama S, Kase H, Borrelli E. Rescue of locomotor impairment in dopamine $\mathrm{D}_{2}$ receptordeficient mice by an adenosine $A_{2 A}$ receptor antagonist. J. Neurosci. 2000; 20:5848-5852. [PubMed: 10908627]

119. Xu K, Bastia E, Schwarzschild M. Therapeutic potential of adenosine $A_{2 A}$ receptor antagonists in Parkinson's disease. Pharmacol. Ther. 2005; 105:267-310. [PubMed: 15737407]

120. Ross GW, et al. Association of coffee and caffeine intake with the risk of Parkinson disease. JAMA. 2000; 283:2674-2679. [PubMed: 10819950]

121. Ascherio A, et al. Prospective study of caffeine consumption and risk of Parkinson's disease in men and women. Ann. Neurol. 2001; 50:56-63. [PubMed: 11456310]

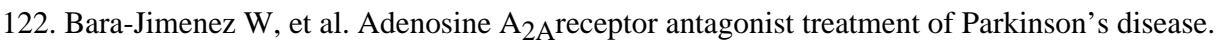
Neurology. 2003; 61:293-296. [PubMed: 12913186]

123. Hauser RA, Hubble JP, Truong DD. Randomized trial of the adenosine A2Areceptor antagonist istradefylline in advanced PD. Neurology. 2003; 61:297-303. [PubMed: 12913187]

124. Weiss SM, et al. Discovery of nonxanthine adenosine $A_{2 A}$ receptor antagonists for the treatment of Parkinson's disease. Neurology. 2003; 61:S101-S106. [PubMed: 14663021]

125. Matasi JJ, et al. The discovery and synthesis of novel adenosine receptor $\mathrm{A}_{2 \mathrm{~A}}$ antagonists. Bioorg. Med. Chem. Lett. 2005; 15:1333-1336. [PubMed: 15713381]

126. Peng $\mathrm{H}$, et al. Novel bicyclic piperazine derivatives of triazolotriazine and triazolopyrimidines as highly potent and selective adenosine $\mathrm{A}_{2 \mathrm{~A}}$ receptor antagonists. J. Med. Chem. 2004; 47:62186229. [PubMed: 15566292]

127. Chen JF, et al. $\mathrm{A}_{2 \mathrm{~A}}$ adenosine receptor deficiency attenuates brain injury induced by transient focal ischemia in mice. J. Neurosci. 1999; 19:9192-9200. [PubMed: 10531422] Provides a genetic basis for treating $\mathrm{PD}$ with $\mathrm{A}_{2 \mathrm{~A}} \mathrm{AR}$ antagonists.

128. Monopoli A, Lozza G, Forlani A, Mattavelli A, Ongini E. Blockade of adenosine A 2 receptors by SCH 58261 results in neuroprotective effects in cerebral ischaemia in rats. Neuroreport. 1998; 9:3955-3959. [PubMed: 9875735]

129. Blum $D$, et al. A dual role of adenosine $A_{2 A}$ receptors in 3-nitropropionic acid-induced striatal lesions: implications for the neuroprotective potential of $A_{2 A}$ antagonists. J. Neurosci. 2003; 23:5361-5369. [PubMed: 12832562]

130. $\mathrm{Yu}$ L, et al. Selective inactivation or reconstitution of adenosine $\mathrm{A}_{2 \mathrm{~A}}$ receptors in bone marrow cells reveals their significant contribution to the development of ischemic brain injury. Nature Med. 2004; 10:1081-1087. [PubMed: 15448683]

131. Aden $U$, et al. Aggravated brain damage after hypoxic ischemia in immature adenosine $\mathrm{A}_{2 \mathrm{~A}}$ knockout mice. Stroke. 2003; 34:739-744. [PubMed: 12624301]

132. Mayne $M$, et al. Adenosine $A_{2 A}$ receptor activation reduces proinflammatory events and decreases cell death following intracerebral hemorrhage. Ann. Neurol. 2001; 49:727-735. [PubMed: 11409424]

133. Cassada DC, et al. Adenosine $\mathrm{A}_{2 \mathrm{~A}}$ agonist reduces paralysis after spinal cord ischemia: correlation with $A_{2 A}$ receptor expression on motor neurons. Ann. Thorac. Surg. 2002; 74:846849. [PubMed: 12238849]

134. von Lubitz DKJE, et al. Postischemic administration of adenosine amine congener (ADAC): analysis of recovery in gerbils. Eur. J. Pharmacol. 1996; 316:171-179. [PubMed: 8982684] 
135. Knutsen LJ, et al. N-substituted adenosines as novel neuroprotective $\mathrm{A}_{1}$ agonists with diminished hypotensive effects. J. Med. Chem. 1999; 42:3463-3477. [PubMed: 10479279]

136. Olsson $\mathrm{T}$, et al. Deletion of the adenosine $\mathrm{A}_{1}$ receptor gene does not alter neuronal damage following ischaemia in vivo or in vitro. Eur. J. Neurosci. 2004; 20:1197-1204. [PubMed: 15341591]

137. Turner $\mathrm{CP}$, et al. $\mathrm{A}_{1}$ adenosine receptors mediate hypoxia-induced ventriculomegaly. Proc. Natl Acad. Sci. USA. 2003; 100:11718-11722. [PubMed: 12975523]

138. Stevens B, Porta S, Haak LL, Gallo V, Fields RD. Adenosine: a neuron-glial transmitter promoting myelination in the CNS in response to action potentials. Neuron. 2002; 36:855-868. [PubMed: 12467589]

139. Linden $J$, et al. Molecular cloning and functional expression of a sheep $A_{3}$ adenosine receptor with widespread tissue distribution. Mol. Pharmacol. 1993; 44:524-532. [PubMed: 8396714]

140. Dixon AK, Gubitz AK, Sirinathsinghji DJ, Richardson PJ, Freeman TC. Tissue distribution of adenosine receptor mRNAs in the rat. Br. J. Pharmacol. 1996; 118:1461-1468. [PubMed: 8832073]

141. Zhao Z, Yaar R, Ladd D, Cataldo LM, Ravid K. Overexpression of $\mathrm{A}_{3}$ adenosine receptors in smooth, cardiac, and skeletal muscle is lethal to embryos. Microvasc. Res. 2002; 63:61-69. [PubMed: 11749073]

142. Jacobson KA, et al. A role for central $\mathrm{A}_{3}$-adenosine receptors. Mediation of behavioral depressant effects. FEBS Lett. 1993; 336:57-60.

143. von Lubitz DKJE, Lin RC-S, Popik P, Carter MF, Jacobson KA. Adenosine $\mathrm{A}_{3}$ receptor stimulation and cerebral ischemia. Eur. J. Pharmacol. 1994; 263:59-67. [PubMed: 7821362]

144. Porkka-Heiskanen T, et al. Adenosine: a mediator of the sleep-inducing effects of prolonged wakefulness. Science. 1997; 276:1265-1268. [PubMed: 9157887] Shows that adenosine is a physiological sleep factor that mediates the somnogenic effects of prior wakefulness.

145. Porkka-Heiskanen T, Alanko L, Kalinchuk A, Stenberg D. Adenosine and sleep. Sleep Med. Rev. 2002; 6:321-332. [PubMed: 12531135]

146. Stenberg D, et al. Sleep and its homeostatic regulation in mice lacking the adenosine $\mathrm{A}_{1}$ receptor. J. Sleep Res. 2003; 12:283-290. [PubMed: 14633239]

147. Urade $Y$, et al. Sleep regulation in adenosine $A_{2 A}$ receptor-deficient mice. Neurology. 2003; 61:S94-S96. [PubMed: 14663019]

148. Basheer R, Strecker RE, Thakkar MM, McCarley RW. Adenosine and sleep-wake regulation. Prog. Neurobiol. 2004; 73:379-396. [PubMed: 15313333]

149. Yao $L$, et al. $\beta \gamma$ dimers mediate synergy of dopamine $D_{2}$ and adenosine $A_{2}$ receptor-stimulated PKA signalling and regulate ethanol consumption. Cell. 2002; 109:733-743. [PubMed: 12086672]

150. Mailliard WS, Diamond I. Recent advances in the neurobiology of alcoholism: the role of adenosine. Pharmacol. Ther. 2004; 101:39-46. [PubMed: 14729391]

151. Bauer A, et al. ${ }^{18} \mathrm{~F}-\mathrm{CPFPX}$ PET identifies changes in cerebral $\mathrm{A}_{1}$ adenosine receptor density caused by glioma invasion. J. Nucl. Med. 2005; 46:450-454. [PubMed: 15750158]

152. Moresco RM, et al. In vivo imaging of adenosine $\mathrm{A}_{2 \mathrm{~A}}$ receptors in rat and primate brain using $\left[{ }^{11} \mathrm{C}\right] \mathrm{SCH} 442416$. Eur. J. Nucl. Med. Mol. Imaging. 2005; 32:405-413. [PubMed: 15549298]

153. El Yacoubi M, et al. Absence of the adenosine $A_{2 A}$ receptor or its chronic blockade decrease ethanol withdrawal-induced seizures in mice. Neuropharmacology. 2001; 40:424-432. [PubMed: 11166335]

154. Lee HT, Emala CW. Protective effects of renal ischemic preconditioning and adenosine pretreatment: role of $A_{1}$ and $A_{3}$ receptors. Am. J. Physiol. Renal Physiol. 2000; 278:F380-F387. [PubMed: 10710542]

155. Pingle SC, et al. Osmotic diuretics induce adenosine $\mathrm{A}_{1}$ receptor expression and protect renal proximal tubular epithelial cells against cisplatin-mediated apoptosis. J. Biol. Chem. 2004; 279:43157-43167. [PubMed: 15272017]

156. Brown R, et al. Abolished tubuloglomerular feedback and increased plasma renin in adenosine $A_{1}$ receptor-deficient mice. Am. J. Physiol. Regul. Integr. Comp. Physiol. 2001; 281:R1362-R1367. [PubMed: 11641103] 
157. Sun D, et al. Mediation of tubuloglomerular feedback by adenosine: evidence from mice lacking adenosine $A_{1}$ receptors. Proc. Natl Acad. Sci. USA. 2001; 98:9983-9988. [PubMed: 11504952]

158. Lee HT, Xu H, Nasr SH, Schnermann J, Emala CW. A 1 adenosine receptor knockout mice exhibit increased renal injury following ischemia and reperfusion. Am. J. Physiol. Renal Physiol. 2004; 286:F298-F306. [PubMed: 14600029]

159. Wilcox CS, Welch WJ, Schreiner GF, Belardinelli L. Natriuretic and diuretic actions of a highly selective adenosine $A_{1}$ receptor antagonist. J. Am. Soc. Nephrol. 1999; 10:714-720. [PubMed: 10203354]

160. Gottlieb SS, et al. BG9719 (CVT-124), an $\mathrm{A}_{1}$ adenosine receptor antagonist, protects against the decline in renal function observed with diuretic therapy. Circulation. 2002; 105:1348-1353. [PubMed: 11901047]

161. Auchampach JA, et al. Comparison of three different $A_{1}$ adenosine receptor antagonists on infarct size and multiple cycle ischemic preconditioning in anesthetized dogs. J. Pharmacol. Exp. Ther. 2004; 308:846-856. [PubMed: 14634049]

162. Day YJ, et al. Renal protection from ischemia mediated by $A_{2 A}$ adenosine receptors on bone marrowderived cells. J. Clin. Invest. 2003; 112:883-891. [PubMed: 12975473]

163. Okusa MD, et al. $A_{2 A}$ adenosine receptor-mediated inhibition of renal injury and neutrophil adhesion. Am. J. Physiol. Renal Physiol. 2000; 279:F809-F818. [PubMed: 11053040]

164. Zannikos PN, et al. Pharmacokinetics and safety of single intravenous infusions of the adenosine agonist, AMP 579, in patients with end-stage renal insufficiency. J. Clin. Pharmacol. 2000; 40:745-751. [PubMed: 10883416]

165. Vitzthum H, Weiss B, Bachleitner W, Kramer BK, Kurtz A. Gene expression of adenosine receptors along the nephron. Kidney Int. 2004; 65:1180-1190. [PubMed: 15086457]

166. Cooper J, Hill SJ, Alexander SP. An endogenous A2B adenosine receptor coupled to cyclic AMP generation in human embryonic kidney (HEK 293) cells. Br. J. Pharmacol. 1997; 122:546-550. [PubMed: 9351513]

167. Dubey RK, Gillespie DG, Mi Z, Jackson EK. Adenosine inhibits PDGF-induced growth of human glomerular mesangial cells via $\mathrm{A}_{2 \mathrm{~B}}$ receptors. Hypertension. 2005; 46:628-634. [PubMed: 16103269]

168. Lee HT, et al. A3 adenosine receptor knockout mice are protected against ischemia- and myoglobinuriainduced renal failure. Am. J. Physiol. Renal Physiol. 2003; 284:F267-F273. [PubMed: 12388399]

169. Sun CX, et al. A protective role for the $A_{1}$ adenosine receptor in adenosine-dependent pulmonary injury. J. Clin. Invest. 2005; 115:35-43. [PubMed: 15630442] Uses A AR- and adenosine deaminase-deficient mice to show the occurrence of anti-inflammatory actions of adenosine in the lung, mediated through $\mathrm{A}_{1}$ ARs, on macrophages.

170. Holgate ST. The identification of the adenosine $A_{2 B}$ receptor as a novel therapeutic target in asthma. Br. J. Pharmacol. 2005; 145:1009-1015. [PubMed: 15980878] Comprehensive description of the role of the $A_{2 B} A R$ in asthma, which provides a firm basis for developing $\mathrm{A}_{2 \mathrm{~B}} \mathrm{AR}$ antagonists as a new therapeutic approach to this disease.

171. Salvatore $C A$, et al. Disruption of the $A_{3}$ adenosine receptor gene in mice and its effect on stimulated inflammatory cells. J. Biol. Chem. 2000; 275:4429-4434. [PubMed: 10660615]

172. Feoktistov I, Biaggioni I. Role of adenosine in asthma. Drug Dev. Res. 1996; 39:333-336. [PubMed: 11542498]

173. Ryzhov S, et al. Adenosine-activated mast cells induce IgE synthesis by B lymphocytes: an $\mathrm{A}_{2 \mathrm{~B}^{-}}$ mediated process involving Th2 cytokines IL-4 and IL-13 with implications for asthma. J. Immunol. 2004; 172:7726-7733. [PubMed: 15187156]

174. Auchampach JA, Jin X, Wan TC, Caughey GH, Linden J. Canine mast cell adenosine receptors: cloning and expression of the $\mathrm{A}_{3}$ receptor and evidence that degranulation is mediated by the $A_{2 B}$ receptor. Mol. Pharmacol. 1997; 52:846-860. [PubMed: 9351976]

175. Press $\mathrm{NJ}$, et al. A new orally bioavailable dual adenosine $\mathrm{A}_{2 \mathrm{~B}} / \mathrm{A}_{3}$ receptor antagonist with therapeutic potential. Bioorg. Med. Chem. Lett. 2005; 15:3081-3085. [PubMed: 15876531] 
176. Fozard JR, Ellis KM, Villela Dantas MF, Tigani B, Mazzoni L. Effects of CGS 21680, a selective adenosine $\mathrm{A}_{2 \mathrm{~A}}$ receptor agonist, on allergic airways inflammation in the rat. Eur. J. Pharmacol. 2002; 438:183-188. [PubMed: 11909610]

177. Glaxo Group Ltd: WO9967263, WO9967264, WO9967265 \& WO9967266. Selective A 2 A receptor agonists as inhibitors of cellular activation. Expert Opin. Ther. Pat. 2000; 10:723-728.

178. Rivo J, Zeira E, Galun E, Matot I. Activation of $\mathrm{A}_{3}$ adenosine receptor provides lung protection against ischemia-reperfusion injury associated with reduction in apoptosis. Am. J. Transplant. 2004; 4:1941-1948. [PubMed: 15575895]

179. Sitkovsky MV, et al. Physiological control of immune response and inflammatory tissue damage by hypoxiainducible factors and adenosine $A_{2 A}$ receptors. Annu. Rev. Immunol. 2004; 22:657682. [PubMed: 15032592] Comprehensive overview of the roles of $\mathrm{A}_{2 \mathrm{~A}} \mathrm{ARs}$ in immune response and inflammation-related tissue damage.

180. Erdmann AA, et al. Activation of Th1 and Tc1 cell adenosine $\mathrm{A}_{2 \mathrm{~A}}$ receptors directly inhibits IL-2 secretion in vitro and IL-2 driven expansion in vivo. Blood. 2005; 105:4707-4714. [PubMed: 15746085]

181. Lappas CM, Rieger JM, Linden J. A2A adenosine receptor induction inhibits IFN-production in murine CD4+ T cells. J. Immunol. 2005; 174:1073-1080. [PubMed: 15634932]

182. Ohta A, Sitkovsky M. Role of G-protein-coupled adenosine receptors in downregulation of inflammation and protection from tissue damage. Nature. 2001; 414:916-920. [PubMed: 11780065] Describes that $A_{2 A} A R s$ are crucially involved in the limitation and termination of inflammation. No other mechanism for inflammation could compensate fully for the loss of $\mathrm{A}_{2 \mathrm{~A}}$ ARs on immune cells.

183. Kirkpatrick P. Putting the brake on inflammation. Nature Rev. Drug Disc. 2002; 1:99.

184. Montesinos $\mathrm{MC}$, et al. Adenosine $\mathrm{A}_{2 \mathrm{~A}}$ or $\mathrm{A}_{3}$ receptors are required for inhibition of inflammation by methotrexate and its analog MX-68. Arthritis Rheum. 2003; 48:240-247. [PubMed: 12528125]

185. Day YJ, et al. Protection from ischemic liver injury by activation of $\mathrm{A}_{2 \mathrm{~A}}$ adenosine receptors during reperfusion: inhibition of chemokine induction. Am. J. Physiol. Gastrointest. Liver Physiol. 2004; 286:G285-G293. [PubMed: 14715520]

186. Sullivan GW, Fang G, Linden J, Scheld WM. A 2 A adenosine receptor activation improves survival in mouse models of endotoxemia and sepsis. J. Infect. Dis. 2004; 189:1897-1904. [PubMed: 15122527]

187. Odashima $\mathrm{M}$, et al. Activation of $\mathrm{A}_{2 \mathrm{~A}}$ adenosine receptor attenuates intestinal inflammation in animal models of inflammatory bowel disease. Gastroenterology. 2005; 129:26-33. [PubMed: 16012931]

188. Peirce SM, Skalak TC, Rieger JM, Macdonald TL, Linden J. Selective $A_{2 A}$ adenosine receptor activation reduces skin pressure ulcer formation and inflammation. Am. J. Physiol. Heart Circ. Physiol. 2001; 281:H67-H74. [PubMed: 11406470]

189. Montesinos MC, et al. Wound healing is accelerated by agonists of adenosine A2 (Gas-linked) receptors. J. Exp. Med. 1997; 186:1615-1620. [PubMed: 9348321]

190. Ramkumar V, Stiles GL, Beaven MA, Ali H. The $A_{3}$ adenosine receptor is the unique adenosine receptor which facilitates release of allergic mediators in mast cells. J. Biol. Chem. 1993; 268:16887-16890. [PubMed: 8349579]

191. Haskó G, Cronstein BN. Adenosine: an endogenous regulator of innate immunity. Trends Immunol. 2004; 25:33-39. [PubMed: 14698282] Summary of adenosine's promotion of a selflimiting, healthy immune response in endothelial cells, neutrophils and mast cells.

192. Baharav E, et al. Antiinflammatory effect of $A_{3}$ adenosine receptor agonists in murine autoimmune arthritis models. J. Rheumatol. 2005; 32:469-476. [PubMed: 15742438]

193. Dong Q, Ginsberg HN, Erlanger BF. Overexpression of the $A_{1}$ adenosine receptor in adipose tissue protects mice from obesity-related insulin resistance. Diabetes Obes. Metab. 2001; 3:360366. [PubMed: 11703426]

194. Harada H, et al. 2-Alkynyl-8-aryl-9-methyladenines as novel adenosine receptor antagonists: their synthesis and structure-activity relationships toward hepatic glucose production induced via agonism of the $\mathrm{A}_{2 \mathrm{~B}}$ receptor. J. Med. Chem. 2001; 44:170-179. [PubMed: 11170626] 
195. Kohno Y, Sei Y, Koshiba M, Kim HO, Jacobson KA. Induction of apoptosis in HL-60 human promyelocytic leukemia cells by adenosine $\mathrm{A}_{3}$ receptor agonists. Biochem. Biophys. Res. Commun. 1996; 219:904-910. [PubMed: 8645277]

196. Kim SG, et al. p53-Independent induction of Fas and apoptosis in leukemic cells by an adenosine derivative, Cl-IB-MECA. Biochem. Pharmacol. 2002; 63:871-880. [PubMed: 11911839]

197. Gao Z, Li BS, Day YJ, Linden J. A 3 adenosine receptor activation triggers phosphorylation of protein kinase $\mathrm{B}$ and protects rat basophilic leukemia $2 \mathrm{H} 3$ mast cells from apoptosis. Mol. Pharmacol. 2001; 59:76-82. [PubMed: 11125027]

198. Neary JT, McCarthy M, Kang Y, Zuniga S. Mitogenic signalling from P1 and P2 purinergic receptors to mitogen-activated protein kinase in human fetal astrocyte cultures. Neurosci. Lett. 1998; 242:159-162. [PubMed: 9530930]

199. Merighi S, et al. Adenosine receptors as mediators of both cell proliferation and cell death of cultured human melanoma cells. J. Invest. Dermatol. 2002; 119:923-933. [PubMed: 12406340]

200. Fishman P, Bar-Yehuda S, Madi L, Cohn I. A 3 adenosine receptor as a target for cancer therapy. Anticancer Drugs. 2002; 13:437-443. [PubMed: 12045454]

201. Madi $\mathrm{L}$, et al. The $\mathrm{A}_{3}$ adenosine receptor is highly expressed in tumor versus normal cells: potential target for tumor growth inhibition. Clin. Cancer Res. 2004; 10:4472-4479. [PubMed: 15240539] Shows that colon and breast carcinoma tissues have higher $A_{3} A R$ expression in the tumour versus adjacent non-neoplastic tissue or normal tissue, which provided a basis for the use of $\mathrm{A}_{3} \mathrm{AR}$ agonists in cancer therapy.

202. Lu J, Pierron A, Ravid K. An adenosine analogue, IB-MECA, down-regulates estrogen receptor alpha and suppresses human breast cancer cell proliferation. Cancer Res. 2003; 63:6413-6423. [PubMed: 14559831]

203. Avila MY, Stone RA, Civan MM. Knockout of $A_{3}$ adenosine receptors reduces mouse intraocular pressure. Invest. Ophthalmol. Vis. Sci. 2002; 43:3021-3026. [PubMed: 12202525]

204. Okamura $T$, et al. Structure-activity relationships of adenosine $A_{3}$ receptor ligands: new potential therapy for the treatment of glaucoma. Bioorg. Med. Chem. Lett. 2004; 14:3775-3779. [PubMed: 15203160]

205. Jacobson KA, et al. Neoceptor concept based on molecular complementarity in GPCRs: a mutant adenosine $\mathrm{A}_{3}$ receptor with selectively enhanced affinity for amine-modified nucleosides. $\mathrm{J}$. Med. Chem. 2001; 44:4125-4136. [PubMed: 11708915]

206. Jacobson KA, et al. A neoceptor approach to unraveling microscopic interactions between the human $\mathrm{A}_{2 \mathrm{~A}}$ adenosine receptor and its agonists. Chem. Biol. 2005; 12:237-247. [PubMed: 15734651]

207. Klotz KN, et al. Comparative pharmacology of human adenosine receptor subtypes characterization of stably transfected receptors in CHO cells. Naunyn Schmiedebergs Arch. Pharmacol. 1998; 357:1-9. [PubMed: 9459566]

208. Palle VP, et al. Structure-affinity relationships of the affinity of 2-pyrazolyl adenosine analogues for the adenosine $\mathrm{A}_{2 \mathrm{~A}}$ receptor. Bioorg. Med. Chem. Lett. 2002; 12:2935-2939. [PubMed: 12270178]

209. Gao ZG, et al. Orthogonal activation of the reengineered $A_{3}$ adenosine receptor (neoceptor) using tailored nucleoside agonists. J. Med. Chem. (in the press). 


\section{Box 1}

\section{Neoceptors}

Because of the widespread distribution of native adenosine receptors (ARs), their activation is inherently nonselective. To address this issue, efforts have been made to reengineer ARs into 'neoceptors' that can recognize uniquely modified nucleosides that are inactive at the native ARs ${ }^{38,205,206}$. This neoceptor strategy, which is intended for eventual use in organ-targeted gene therapy, is made possible by modelling of the putative ligand-binding site of a G-protein-coupled receptor, leading to identification of sites for mutagenesis, and incorporation of a complementary functional group in a synthetic agonist (neoligand). A novel electrostatic or H-bonding pair formed between the neoceptor and neoligand allows receptor activation that is orthogonal with respect to the native species ${ }^{209}$. So far, neoceptors have been developed for $\mathrm{A}_{2 \mathrm{~A}}$ and $\mathrm{A}_{3} \mathrm{ARs}$. 


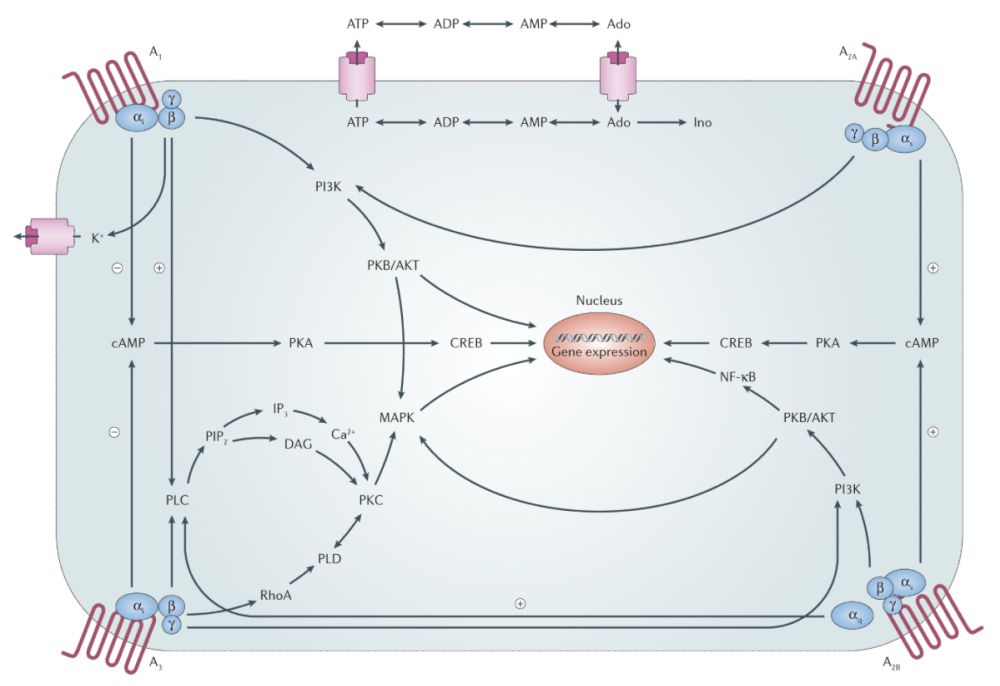

Figure 1. Adenosine receptor signalling pathways

Activation of the $A_{1}$ and $A_{3}$ adenosine receptors (ARs) inhibits adenylyl cyclase activity through activation of pertussis toxin-sensitive $G_{i}$ proteins and results in increased activity of phospholipase $C$ (PLC) via $G_{\beta \gamma}$ subunits. Activation of the $A_{2 A}$ and $A_{2 B} A R s$ increases adenylyl cyclase activity through activation of $G_{s}$ proteins. Activation of the $A_{2 A} A R$ to induce formation of inositol phosphates can occur under certain circumstances, possibly via the pertussis toxin-insensitive Ga15 and Ga16 proteins. $\mathrm{A}_{2 \mathrm{~B}} \mathrm{AR}$-induced activation of PLC is through $\mathrm{G}_{\mathrm{q}}$ proteins. All four subtypes of ARs can couple to mitogen-activated protein kinase (MAPK), giving them a role in cell growth, survival, death and differentiation. $\mathrm{CREB}$, cAMP response element binding protein; DAG, diacylglycerol; $\mathrm{IP}_{3}$, inositol 1,4,5trisphosphate; PI3K, phosphatidylinositol 3-kinase; $\mathrm{PIP}_{2}$, phosphatidylinositol-4,5bisphosphate; PK, protein kinase; PLD, phospholipase D; NF- $\kappa \mathrm{B}$, nuclear factor- $\kappa \mathrm{B}$. 


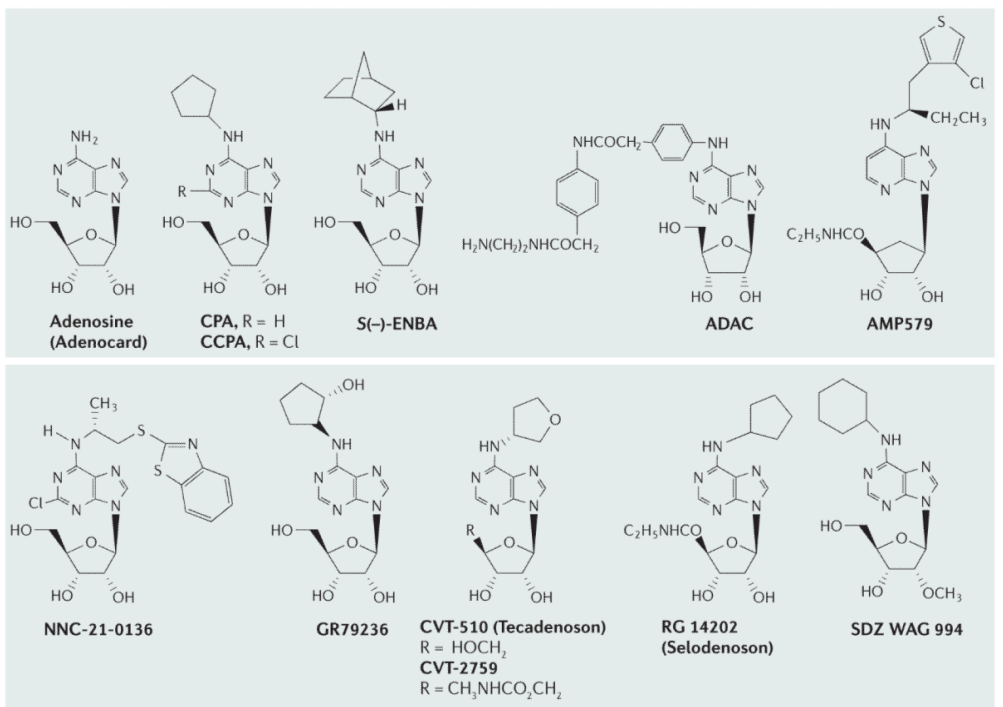

Figure 2. Adenosine receptor agonists

Adenosine receptor (AR) agonists acting at the $\mathrm{A}_{1} \mathrm{AR}$. $K_{\mathrm{i}}$ values for binding to ARs are given in TABLE 1. 


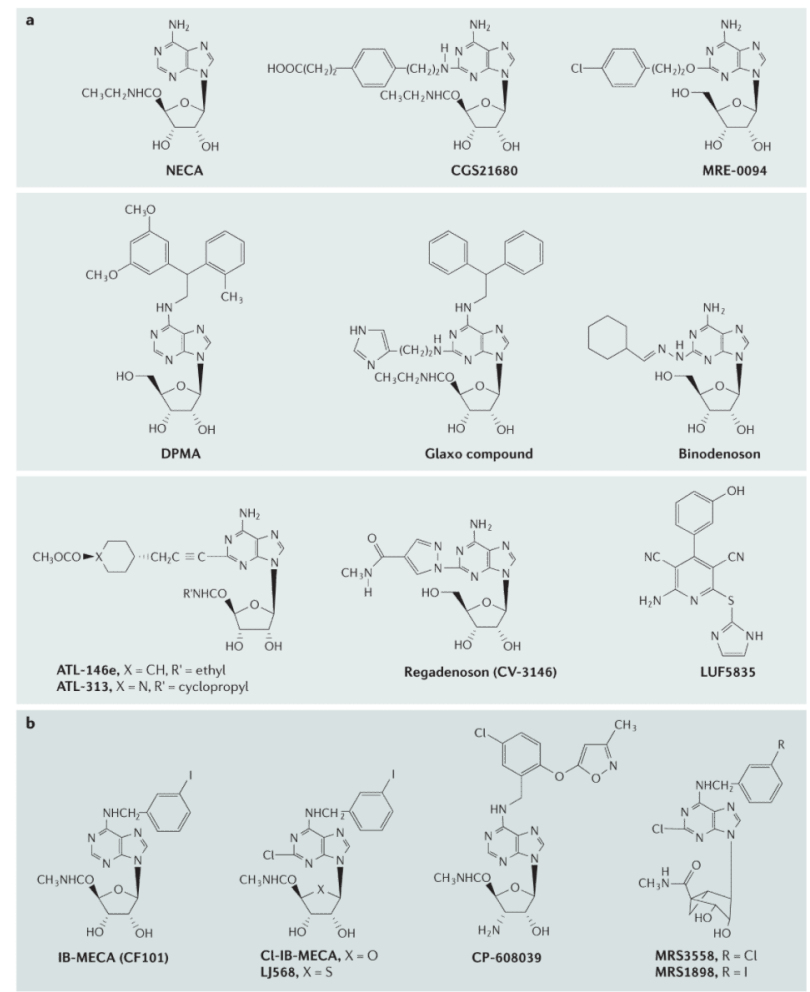

Figure 3. Adenosine receptor agonists

a I Adenosine receptor (AR) agonists acting at the $\mathrm{A}_{2 \mathrm{~A}} \mathrm{AR}$. LUF5835 $\left(\mathrm{EC}_{50}\right.$ of $\left.10 \mathrm{nM}\right)$ is an atypical $\mathrm{A}_{2 \mathrm{~B}} \mathrm{AR}$ agonist ${ }^{52}$. b I $\mathrm{AR}$ agonists selective for the $\mathrm{A}_{3} \mathrm{AR}$. $K_{\mathrm{i}}$ values for binding to ARs are given in TABLE 1. 

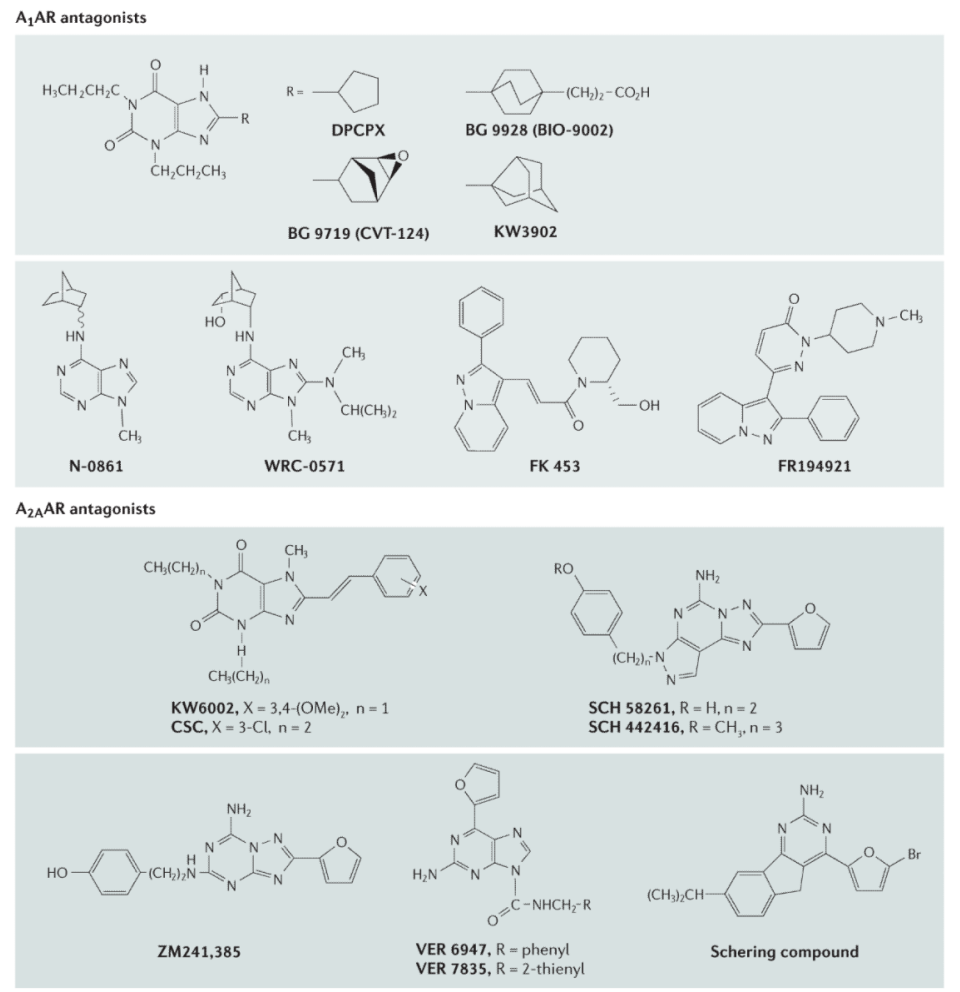

Figure 4. Adenosine receptor antagonists

Antagonists acting at the $\mathrm{A}_{1}$ adenosine receptors $\left(\mathrm{A}_{1} \mathrm{ARs}\right)$ and $\mathrm{A}_{2 \mathrm{~A}} \mathrm{ARs} . K_{\mathrm{i}}$ values for binding to the ARs are given in TABLE 1. 


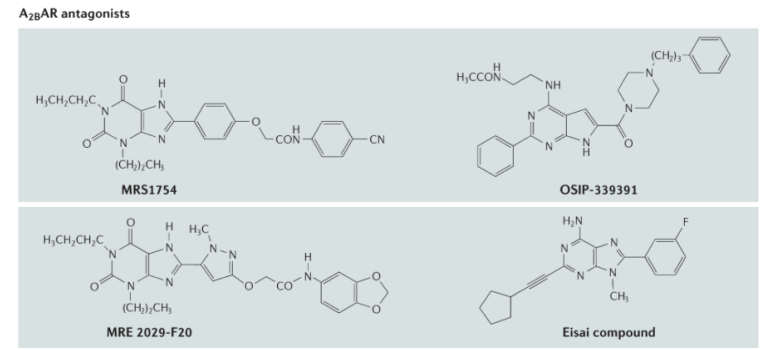

$A_{3} A R$ antagonists
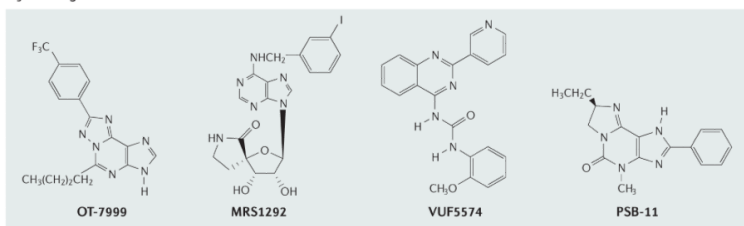

OI-7999

MRS1292 PSB-11

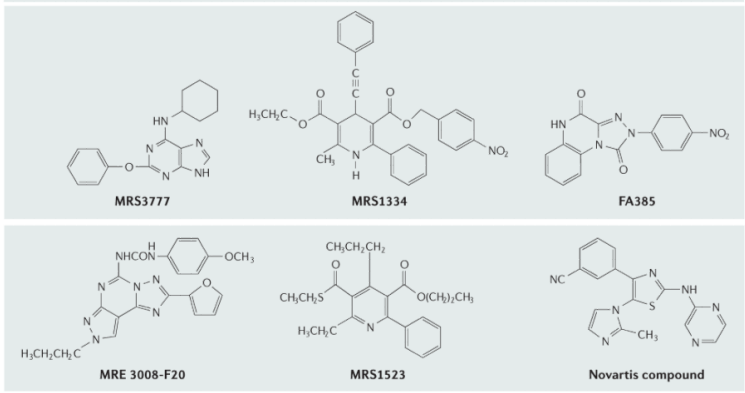

Figure 5. Adenosine receptor antagonists

Antagonists acting at the $\mathrm{A}_{2 \mathrm{~B}}$ and $\mathrm{A}_{3} \mathrm{ARs}^{40}$. Novartis compound has high affinity at human $\mathrm{A}_{2 \mathrm{~B}}$ and $\mathrm{A}_{3} \mathrm{ARs}^{175}$. $K_{\mathrm{i}}$ values for binding to the ARs are given in TABLE 1. 


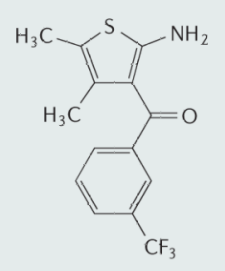

PD81,723

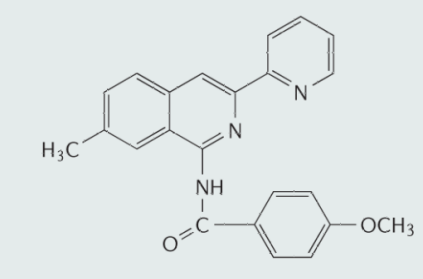

VUF5455

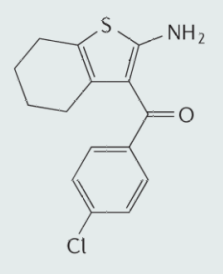

T-62

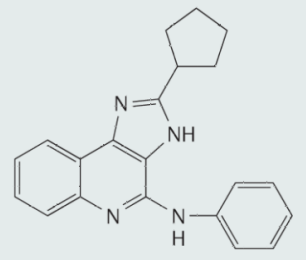

DU124183

Figure 6. Examples of allosteric enhancers of the activity of adenosine receptor agonists PD81,723 and T-62 enhance the activity of agonists acting at the $A_{1}$ adenosine receptor $\left(A_{1} A R\right)$ and VUF5455 and DU124183 enhance the activity of agonists acting at the $A_{3} A^{7}$. 


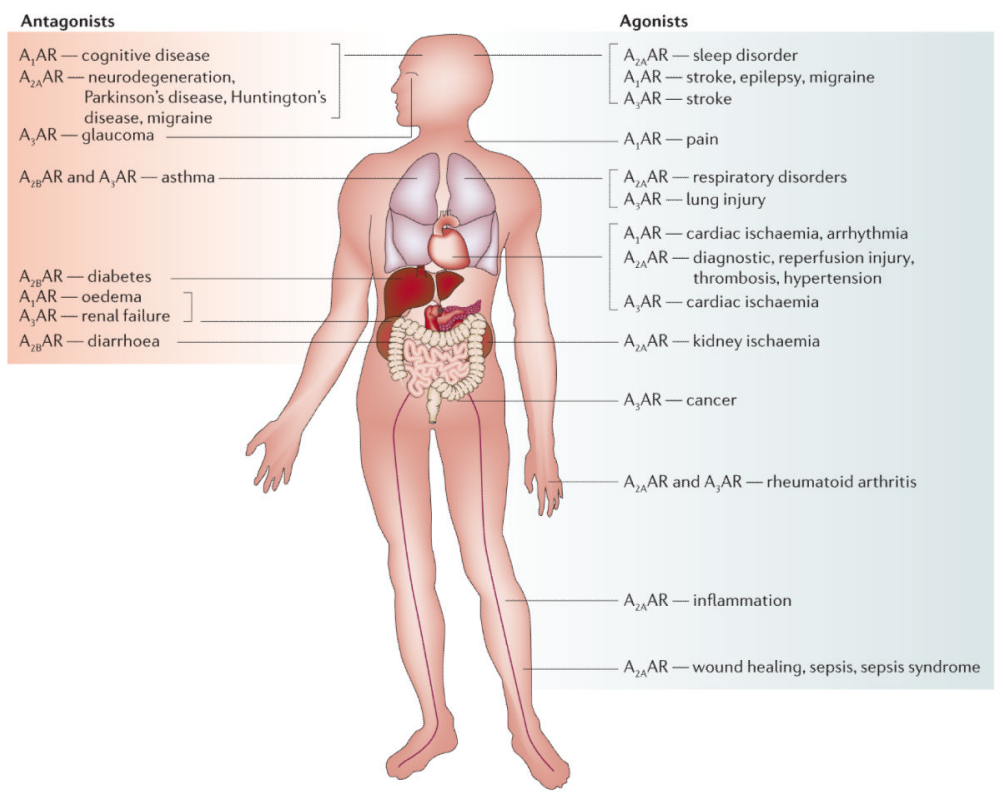

Figure 7. Novel disease targets for selective adenosine receptor ligands

Most promising prospects exist for treatment of arrhythmias, ischaemia of the heart and brain, pain, neurodegenerative diseases, sleep disorders, inflammation, diabetes, renal failure, cancer and glaucoma, and in cardiovascular imaging. High and intermediate levels of $A_{1}$ adenosine receptor (AR) expression were found in the brain, heart, adipose tissue, stomach, vas deferens, testis, spleen, kidney, aorta, liver, eye and bladder ${ }^{140}$. The $\mathrm{A}_{2 \mathrm{~A}} \mathrm{AR}$ is highly expressed in the striatum, nucleus accumbens and olfactory tubercle ${ }^{140}$. High and intermediate expression levels were also found in immune cells, heart, lung and blood vessels. The $A_{2 B} A R$ was generally expressed at low levels in almost all tissues ${ }^{140}$. Rat testis has particularly high concentrations of $\mathrm{A}_{3} \mathrm{AR}$ mRNA, with moderate levels in lung. The highest levels of human $\mathrm{A}_{3} \mathrm{AR}$ mRNA have been found in lung and liver. $\mathrm{A}_{3} \mathrm{ARs}$ have been detected in various tissues including testis, lung, kidney, placenta, heart, brain, spleen, liver, uterus, bladder, jejunum, aorta, proximal colon and eyes. 


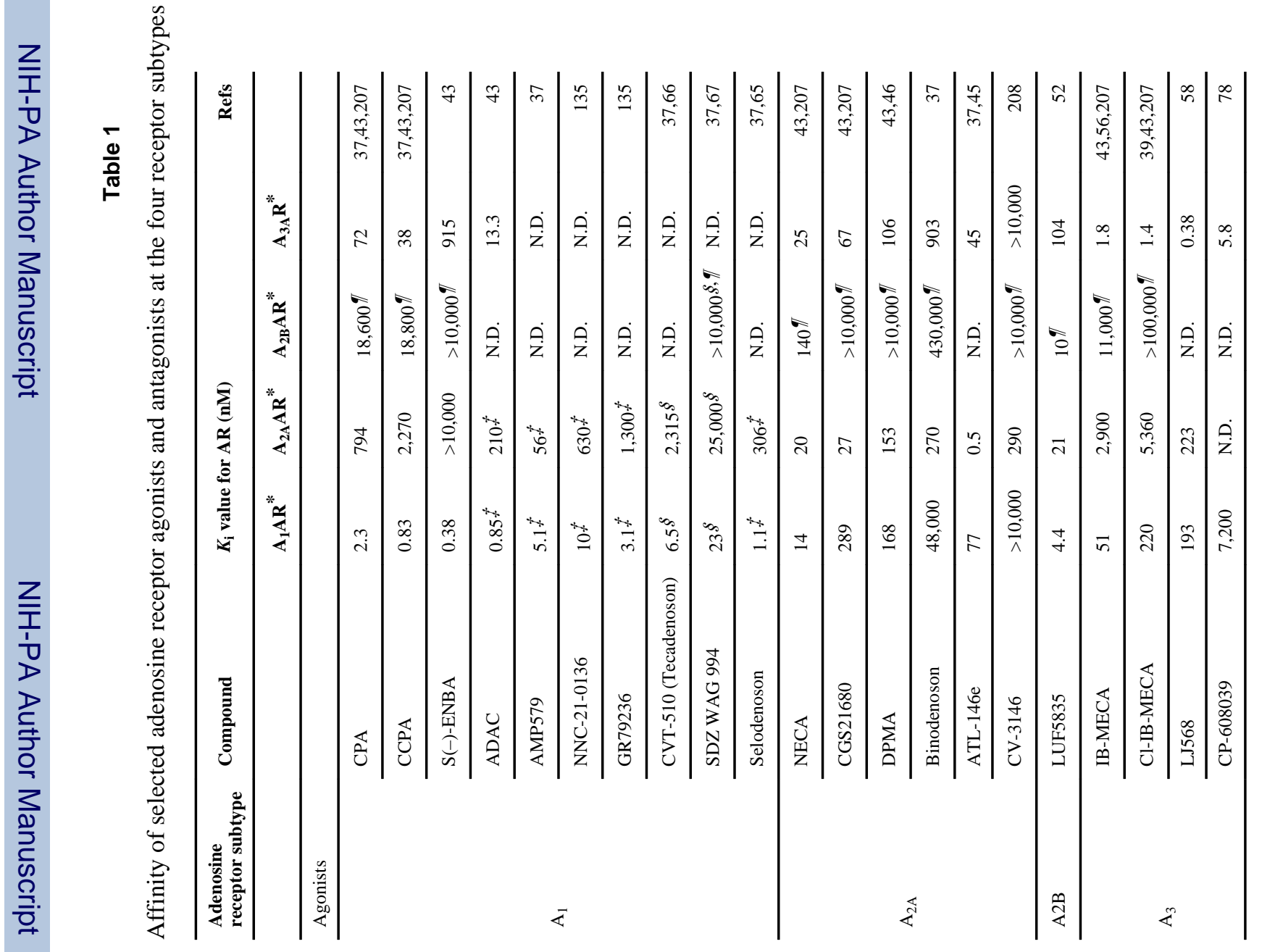




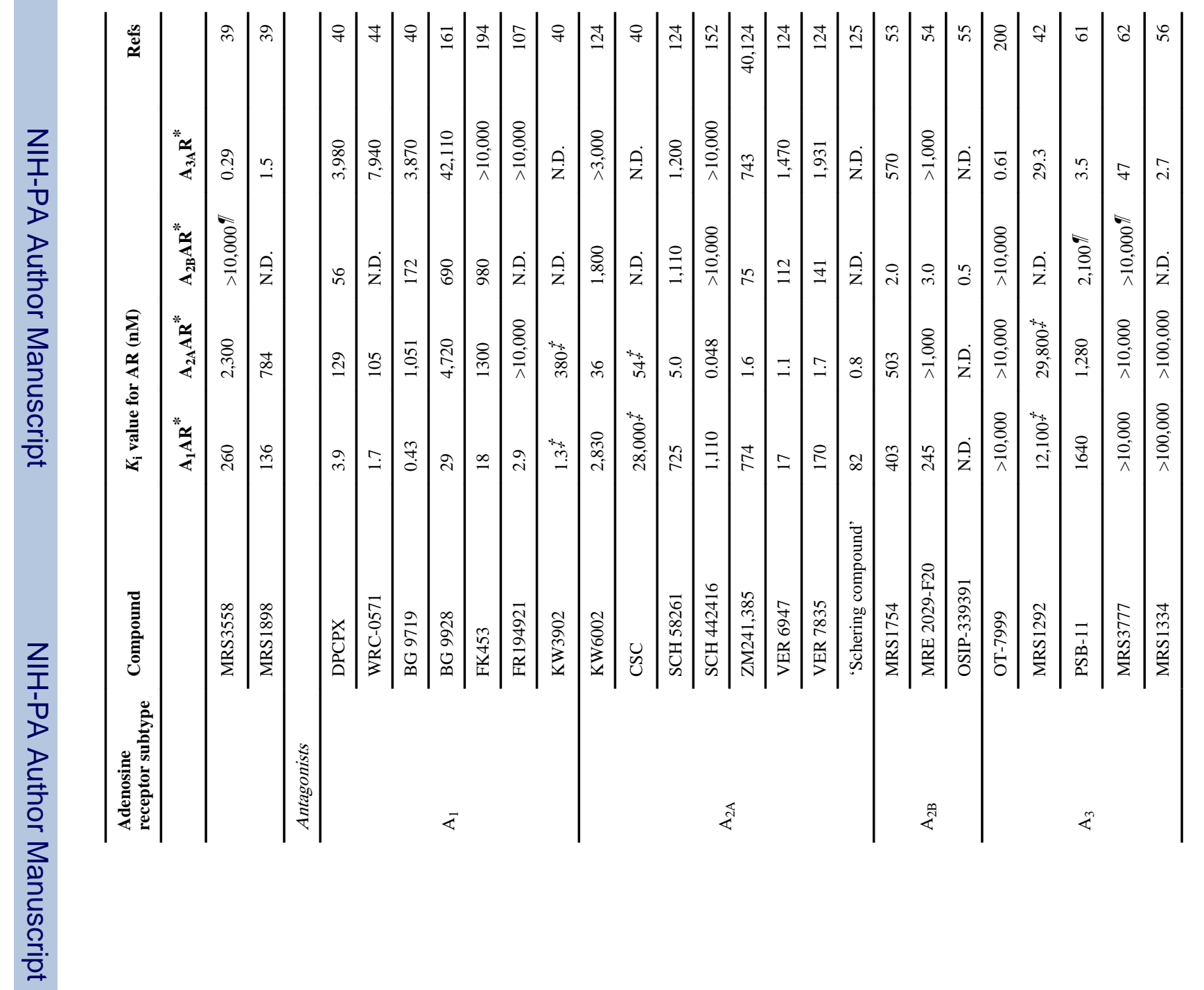

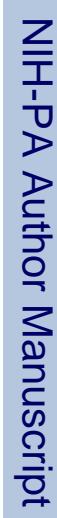




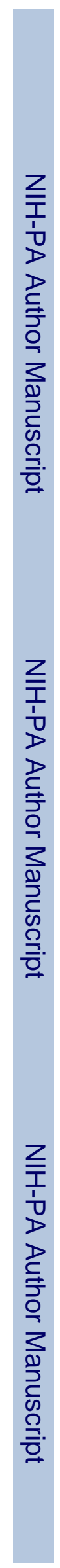

Jacobson and Gao

Page 37

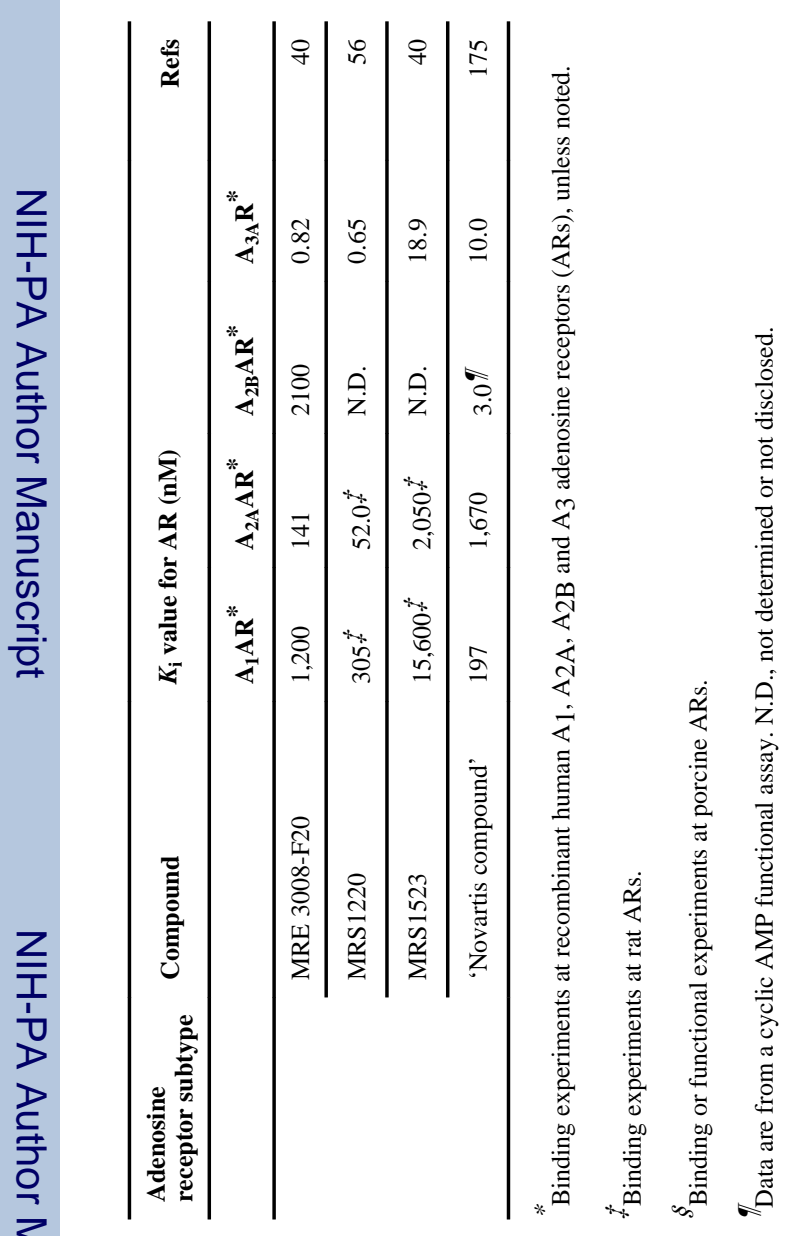



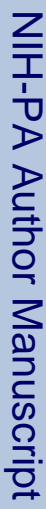

Nat Rev Drug Discov. Author manuscript; available in PMC 2012 October 03. 